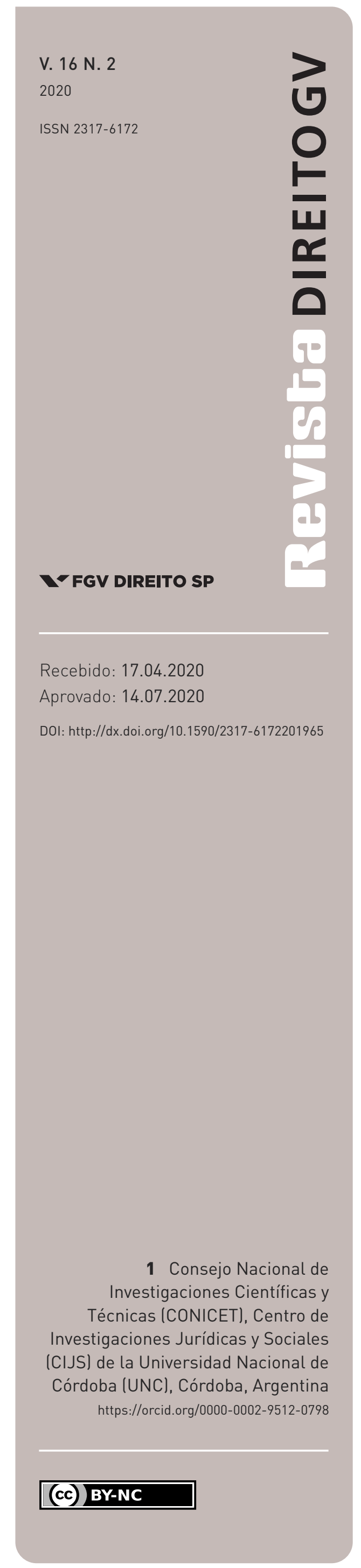

\section{IMF Sovereign Debt Restructuring Framework: Origin, Evolution and Latest Updates of its Main Components}

MARCO PARA REESTRUTURAÇÕES DA DÍVIDA SOBERANA DO FMI: ORIGEM, EVOLUÇÃO E ATUALIZAÇÕES MAIS RECENTES DE SEUS PRINCIPAIS COMPONENTES

Alejandro Gabriel Manzo'

\begin{abstract}
The first introductory manual of the IMF framework for Sovereign Debt Restructurings (SDRs) is introduced in this article. SDR processes, in which billions of dollars are negotiated, constitute key elements for the healthy recovery of an over-indebted economy. However, there are no academic works that analyze in depth the way in which the Fund organizes them. Based on official documents, this paper aims to bridge this gap by explaining how the components that shape the IMF SDR framework are articulated. To this end, the article analyzes: 1) the framework substantial and procedural rules in order to show it as an abstract normative structure as well as an action procedure applicable to specific cases; 2) the framework evolution, synthetically presenting the discussions that gave rise to its main components and justified its principal changes; 3 ) the framework latest updates, which modified sensitive areas of the Fund's surveillance and financing functions. This analytical perspective closes a logical circle that shows the IMF SDR framework in a historical and integral manner and also gives an idealistic insider view to what the Fund is and how it operates.
\end{abstract}

\section{Keywords}

International Monetary Fund (IMF); Sovereign Debt Restructuring (SDR); International Financial Architecture (IFA).

\section{Resumo}

Este artigo apresenta o primeiro manual introdutório sobre o marco do Fundo Monetário Internacional (FMI) para Reestruturações da Dívida Soberana (REDS). Os processos das REDS, nos quais bilhões de dólares são negociados, são processos-chave para o saneamento de uma economia fortemente endividada. Apesar disso, não existem trabalhos na literatura que analisem em profundidade a maneira pela qual o Fundo os organiza. Com base em seus documentos oficiais, este artigo procura preencher essa lacuna explicando como os componentes que moldam seu marco de REDS são articulados. Para esse fim, são levados em consideração: al suas regras substanciais e processuais, para exibi-lo como uma estrutura normativa abstrata e como um procedimento de ação aplicável a casos específicos; b) sua evolução, apresentando sinteticamente os problemas que deram origem aos seus componentes básicos e justificaram suas principais mudanças; cl suas atualizações mais recentes, que modificaram áreas sensíveis das funções de vigilância e financiamento do FMI. Com isso, este trabalho traça um círculo analítico que possibilita o entendimento histórico e integral de seu marco para as REDS e, ao fazê-lo, adicionalmente, permite ao leitor formar uma ideia firme e idealista do que é e como funciona o Fundo.

\section{Palavras-chave}

Fundo Monetário Internacional (FMI); Reestruturação da Dívida Soberana (REDS); Arquitetura Financeira Internacional (AFI). 


\section{INTRODUCTION}

The IMF, the central agent of global financial governance, plays a key role in the organization of Sovereign Debt Restructurings (SDRs). The Fund participates in the previous stages of these processes, seeking to prevent financial crises and collaborating with the restructuring plan design. During the course of an SDR development, it is the de facto arbiter of the negotiations and also determines the role of all the other players. Finally, in the post-restructuring stage, it is the IMF that controls the effectiveness of what has been done (Gelpern, 2014; Manzo, 2019).

Nevertheless, there are no specialized academic works to explain in depth the framework used by the IMF to organize these processes. The articles that address this concern can be classified into two groups.

One of the groups offers elements of the framework in a fragmented and non-systematic manner. In this group, there are works which perform this task in order to: 1) make visible problems of the current SDR regime and problematize proposals for modifying it (GuzmanStiglitz, 2014; Krueger, 2002); 2) specifically explain one of its dimensions (Boughton et al., 2014; Schadler, 2016); 3) describe the content and design process of a particular reform (Sobel, 2016; Makoff-Kahn, 2015); 4) analyze the IMF intervention in concrete SDR cases (Kupelian-Rivas, 2014; Schadler, 2015).

The other group deals with the IMF SDR framework in a single narrative. These works are characterized by watching and observing in a holistic way. However, none of them do it in depth, simply because they do not attempt to do so: these works introduce a brief over view of the framework in order to analyze some of the dimensions mentioned in the preceding paragraph (Gelpern, 2014 and 2016; Manzo 2019; Krueger-Hagan, 2005; Haley, 2017; Buchheit et al., 2018).

One of the causes that justifies this peculiar gap is located in the difference between what the framework "states" and what the Fund "does" in practice. Basically, in the last three relevant SDR cases - Argentina's, Ukraine's and Greece's (respectively, Simpson 2006; Schadler 2015; Boughton et al. 2014)-, the IMF simply abandoned the respective rules of reference. In this sense, it should be noted that this article means to reconstruct this framework not because it holds idealistic illusions about its legal effectiveness, but because it understands that its rules also perform other symbolic functions in society (Bourdieu, 2000).

Another cause which explains this literature gap can be found in its particular complexity. Explaining the content of the IMF framework in depth - as this article intends - is a challenge in itself. This is so because the Fund does not have an international bankruptcy law or similar to organize SDRs by means of a single legal instrument. On the contrary, and as shown in the following chart, the entity performs this task by way of the interrelation of a relatively autonomous set of components. 


\section{CHART 1 - COMPONENTS OFTHE IMF FRAMEWORK FOR SDRs*}

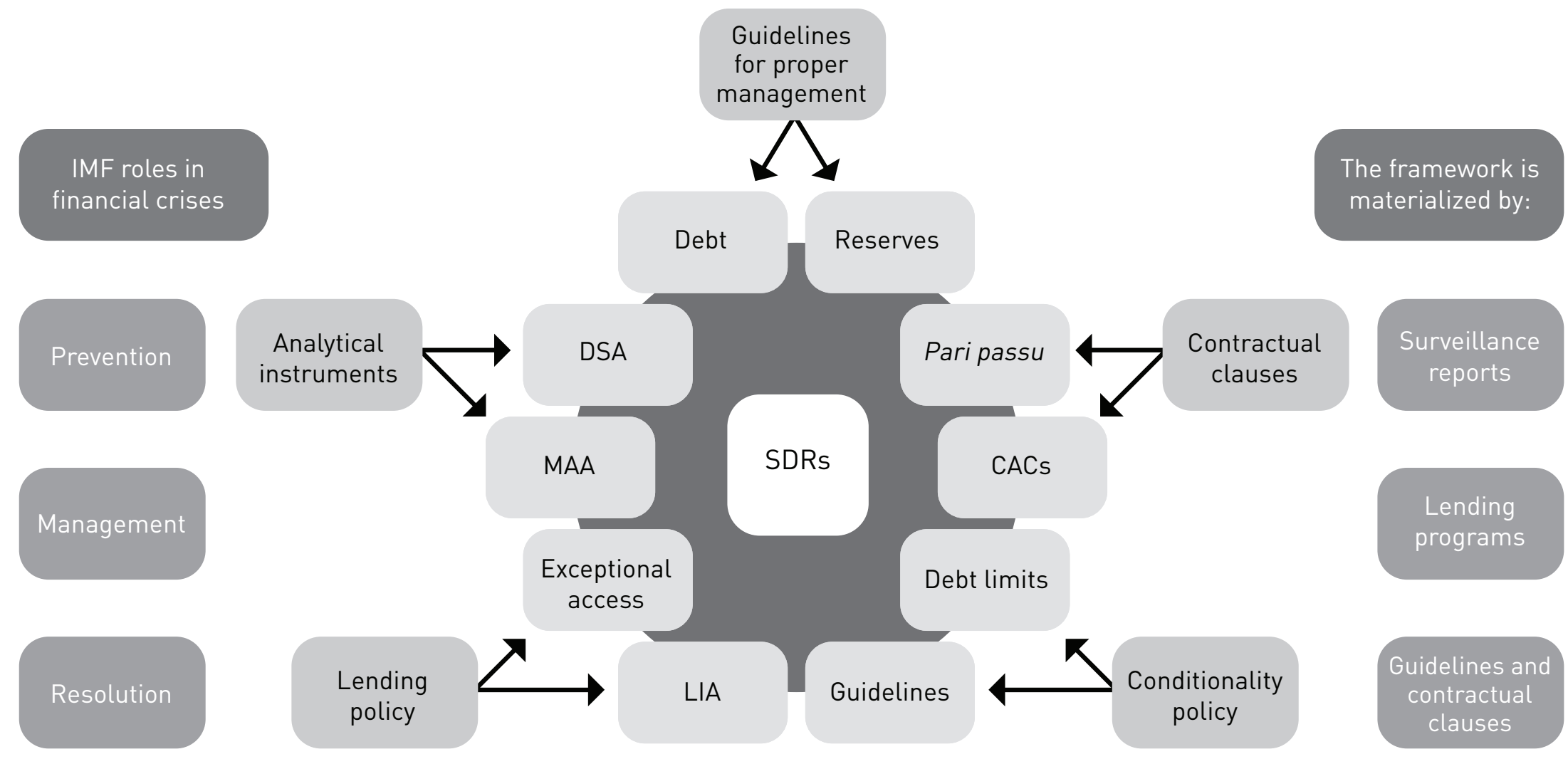

* Abbreviations: see their meaning in annex.

Source: Chart elaborated by the author, based on IMF documents incorporated into the annex.

Taking the IMF official documents as empirical source of data (see annex), this article aims to introduce its SDR framework and show how the components in Chart 1 are currently articulated.

First, there is a general approach to the topic. In particular, this approach means to make a non-specialized reader understand the technique that the IMF uses at the time of organizing this framework, its origin and place in the general SDR regime. It also introduces the criteria that the literature has already used for reconstructing the framework, introducing its own criterion aimed at preserving the benefits and overcoming the limitations of existing reconstructions.

Also, the article shows how the IMF framework ideally works in specific cases. ${ }^{1}$ That is to say, it seeks to show the link between the rules followed by the Fund: on the one hand, to organize its participation in SDR processes and, on the other, to activate such participation

1 For example, the article gives the reader the possibility of having access to the documentation of a particular case - the Argentinean case (see Annex). 
in particular situations. In other words, this framework is reconstructed here in terms of a normative structure applicable in abstract to all cases within its domain and, also, to show the mechanisms stipulated in order to activate this structure in concrete SDR cases.

This way of approaching the object of study is completed by tracing the history of each of the components. In fact, as these components vary over time in a relatively autonomous manner, the characteristics that the SDR framework currently assumes are the result of a specific configuration, which cannot be fully understood if the course of the IMF's own history is not followed. That is why the article works out the evolution of those components, synthetically introducing the discussions that gave rise to them and which justified their main changes.

It should be noted that this task is of special relevance currently, since important reforms have been made in recent years. Formally, the reforms were the result of a report - the "2013 report" - in which the IMF saw a series of limitations and, consequently, proposed a transformation program of its SDR framework (IMF, 2013). Nowadays, three of the four planned reform areas have been already implemented.

This paper closes an analytical circle that allows holistically to appreciate the IMF framework, from its very origin to its present form; it means to offer a privileged view to understand the IMF crisis prevention, management and resolution rules, and to assess its rupture and continuity features after the 2008 global financial crisis.

\section{GENERAL APPROACH TO THE IMF SDR FRAMEWORK: PRESENTATION CRITERION}

There are cases where states cannot honor their sovereign debt. In such situations, states may attempt to restructure the debt, either by refinancing or by reducing the principal or interests. In the current state of development of financial governance, a restructuring cannot be carried out without the consent of creditors. Hence, in practice, states make a restructuring offer that creditors may or may not accept. In the latter case, the conditions of the restructured debt are reflected in new legal instruments or debt "contracts" (Brooks and Lombardi, 2015:1).

In 2014, Lombardi wondered if there really existed an IMF SDR framework and said that he could not be sure that this actually was the case (Lombardi, 2014:23). This point was pertinent since, as already noted, the Fund does not have a specifically designed regulation for organizing these processes and has mentioned the SDR rules under the term "framework" only recently. ${ }^{2}$

2 In IMF documents, it is difficult to find the words "legal and political framework" for SDRs before the aforementioned 2013 report (IMF, 2013). 
These rules emerge in a "residual" manner from other Fund legal and political frameworks (Gelpern, 2014:25). In this sense, it could be said that in a traditional juridical sense, SDRs constitute "deregulated" events, or, more accurately, events whose organization does not arise from an international law per se but rather - residually - from a particular articulation of frameworks created by the IMF for other purposes (see Chart 1).

The frameworks generate rules, in some cases "mandatory" for the member states and Fund staff, while in many others their application by the recipients is "voluntary". Those who stress the weight of voluntary rules tend to state that the IMF SDR framework is "contractual", "decentralized" and "pro-market". These aspects emerge in opposition to those of a hypothetical SDR framework created by means of an international bankruptcy law or similar: in such a case, this framework would be "legal/statutory", "general" and "regulatory" (Manzo, 2019:48-49).

Similarly, specialized scholars wonder whether the role that the IMF currently plays in SDR processes is contemplated or not in its Articles of Agreement. Following a literal interpretation of the language of the Agreement, the answer is negative; that is to say, there is no article or section of article expressly written for SDRs. ${ }^{3}$

Before this legal vacuum, the literature basically offers two positions. One of them advocates for modifying the Agreement in order to concede a "statutory" nature to the functions that the IMF performs in these processes. Krueger is perhaps the most visible representative of this position and her proposal in the early 2000s - known as SDR Mechanism (SDRM) was the most determined attempt to put it into practice (Krueger, 2002).

The other position understands that such modification would be counterproductive and unnecessary because the Fund "entirely acts within the terms of its Agreement" (Tran, 2014: 29). In order to justify it, different authors consider that the IMF's role in SDRs is foreseen in its Agreement, indirectly by means of other mandates (Gelpern, 2014:25): some of them derived from article I, related to the IMF mandate for adjustment of the balance of payments (IMF, 2013:7), and others from articles IV and VI, linked to surveillance and lending roles (Riegner 2016:145; Tran 2014:29).

From a more general perspective, it should be noted that neither is there a unified and homogeneous international SDR “regime”. In Gelpern's words, this regime is constructed in a "modular" way according to the involved kind of creditors (Gelpern, 2016). The central module is precisely that of the IMF, which in practice articulates the rest of the modules in global financial governance.

Formally, this articulation is achieved through agreements signed by financial institutions -for ex., IMF and Paris Club-, and because the frameworks of these institutions refer 
to one another. Informally, the different modules are articulated based on a series of "cross conditionalities" that make it difficult for the debtor to agree with a group of creditors without considering the rest of the creditors (Gelpern, 2016).

From a historical point of view, this regime began in the 1970s, along with the emergence of the so-called "financial globalization". However, it was not until the 1980s, with the outbreak of the external debt crisis, that this regime reached definition by means of a trial and error process (Boughton, 2001).

The early definition was significantly modified in the beginning of the 2000s. These modifications were embedded, in Simpson's terms, in a new orientation of the Fund's policies of "crisis prevention and management" (Simpson, 2006). The post-2013 reforms analyzed in this article were implemented precisely following the configuration that the SDR framework acquired after the modifications; that is to say, the reforms were made following the framework that crystallized in the beginning of the $21^{\text {st }}$ century.

From a political point of view, the emergence of the SDR regime is inextricably linked to the current global financial governance. In fact, it can be said that this governance actually emerged as a response to the debt crisis of the 1980s (Manzo, 2018). At the core of this governance is located a particular interrelation among the G7 countries -with the United States at the center-, the International Financial Institutions (IFIs) and large commercial banks with headquarters precisely in the territories of the G7 countries. The reforms of the SDR regime activated in 2001 and 2013 updated this governance, incorporating or excluding new emerging agents, depending on the circumstances (Manzo, 2019a).

From a juridical point of view, it is relevant to mention that the "rules" that shape this regime are not synonymous with laws. In fact, in the particular case of the IMF, the content of the SDR framework arises from the combination of the prescriptions established, at least, in the following juridical modalities: the Fund's Articles of Agreement, its arrangements with other forums or financial institutions, its reports approved by its governing bodies and, finally, its guidelines directed to its own staff or to a more general public.

The peculiar form that the law assumed here leads to insist on the differentiation between the IMF framework "on paper" and "in practice". The interrelation of the mentioned juridical modalities gives rise to the SDR framework on paper, as this paper means to show. In practice, the framework appears as it is actually performed by the involved agents. The frameworks on paper and in practice never totally overlap. However, there is a particularly widespread coincidence in the literature which considers that, regardless of its juridical coverage, an SDR regime "exists" as a "sociological reality". ${ }^{4}$

4 Recently, Buchheit et al. (2018) and Haley (2017) made an extended effort to show how the SDR regime works in practice. 
Finally, it is appropriate to close this general consideration by observing that in this field there is no univocal criterion for organizing the presentation of the IMF framework. Indeed, an analysis of the specialized literature allowed us to detect three relatively different "presentation criteria".

A first criterion takes into account the Fund's "functions". In general terms, they are divided in two blocks: surveillance and lending functions. The first block is associated with crisis prevention and the second one with crisis management and resolution. In the latter block, scholars include SDRs. ${ }^{5}$ Basically, they show the IMF framework considering the decisions that the Fund must make in order to allow or not to grant financing to a member state. Then, they introduce the SDRs making a parallelism with corporate bankruptcy processes (IMF, 2013; Krueger-Hagan, 2005) or stressing specific aspects of its lending policy (Boughton et al., 2014; Schadler 2016). This way of approaching the object of study has the benefit of emphasizing the IMF's role during an SDR event, but also shows the constraint of erasing the visibility of its role in the surveillance and prevention of crisis.

A second criterion focuses on the "agents". The academic works that take this criterion into account analyze the IMF framework within the more general context of the current SDR regime. The starting point is the identification of the most relevant agents of the sovereign debt market (among others, debtor state, IFIs, Paris and London Club, creditors). ${ }^{6}$ Then, the works show the SDR regime considering the usual practices of agents in these processes, either directly (Buchheit et al., 2018; Haley, 2017) or by dividing the regime into modules (Gelpern, 2016). This way of introducing the object of study has the benefit of embedding the juridical dimension into the way in which the regime actually operates, but also shows the limitations of reducing the relevance of the IMF rules in this general scenario.

Finally, a third criterion operates in relation to the framework "components". Broadly speaking, the authors of this group show the IMF SDR framework using one of these components. ${ }^{7}$ The positive aspect in this instance is the way of accessing the object of study: the chosen component tends to be analyzed in detail. The negative aspect is that these works hinder the observation of the framework in a holistic manner (Gelpern, 2014:25).

This paper proposes the author's own criterion to organize this presentation with the aim of overcoming the mentioned limitations while retaining the benefits of previous criteria. In fact, the reconstruction of the IMF framework is carried out here considering the "time" in relation to a hypothetical crisis event in a member state.

5 In this way, for example, the Peterson Institute (PIIE) conference was organized (PIIE, 2014).

6 See the involved agents in Gulati M. and Gelpern (2006).

7 See works in the introduction that present elements of the framework in a fragmented and non-systematic manner. 
IMF SOVEREIGN DEBT RESTRUCTURING FRAMEWORK: ORIGIN, EVOLUTION AND LATEST UPDATES OF ITS MAIN COMPONENTS : 8

Firstly, as shown below, the article places the reader at a time when a debtor state is not yet confronted with an economic distress situation. At such moment, it introduces the dimensions of the framework that seek to prevent a crisis or, considering that an SDR was necessary, that would serve to organize it in the most appropriate way. Secondly, the paper locates the reader in a scenario where a state is at the start of an economic distress situation. Here, the framework elements linked to the design of the restructuring plan are stressed. Finally, the article places the reader in a context in which the state has already initiated an SDR event, and is aware of the dimensions of the framework that situate the Fund as arbitrator and coordinator of these processes.

Such moments are presented, initially, in an introduction in which the most general notions of the SDR framework are outlined. Secondly, the historical evolution of the components of the framework is shown. To this end, the IMF official documents exhibited in Annex 1 are a reliable empirical source because they describe the problems and debates that activated the reform process, the content of the reform, and the corresponding background; that is, the documents quote other official documents that preceded and supported them. Finally, the rules that give a concrete substance to this framework in each moment are introduced, by making a detailed analysis of such documents in the last reform version.

\section{FINANCIAL CRISES PREVENTION: TRYING TO AVOID OR ANTICIPATE A POSSIBLE SOVEREIGN} DEBT RESTRUCTURING

The IMF's role in SDRs begins before the debtor state has fallen into an economic distress situation by means of its "surveillance function".

As Horsefield explains, during the first decades of existence of the IMF this function was the backbone of the Fund's work. Until the 1970s, surveillance was carried out by means of voluntary consultations with member states. In 1978, with the reform of the Articles of Agreement, these consultations became mandatory, giving birth to what is known as "hard" or "article IV" surveillance. Since then, this function has been expanding, covering a growing number of issues, new control capabilities and analytical tools (Horsefield, 1969:408; Boughton, 2014:5).

The notion of "financial crisis prevention", as a specificity of the Fund surveillance, is much more recent. Indeed, it was only in the end of the $20^{\text {th }}$ century and in the beginning of the $21^{\text {st }}$ century that this notion acquired weight in the discourse of the IMF (Simpson, 2006). Similarly, it was in this context that the IMF made relevant efforts to prevent possible over-indebtedness situations, making operational a set of key instruments for understanding its current SDR framework.

In abstract, the word "prevention" is usually associated without further relation to positive values. In a more concrete sense, this is not necessarily so. This is precisely the case of the IMF, whose notion of "crisis prevention" receives criticism from both extremes of the academic field. From an orthodox position, it is noted that crises are necessary events for the proper 
functioning of the system. Through its intervention, the Fund prevents the market from triggering its own self-regulated mechanisms for eliminating inefficient practices and policies (Maziar, 2014). From a heterodox position, it is stated that, through prevention, the IMF increases its capacity to expand and impose neoliberalism: the ideology that, ultimately, is the cause of crises in the age of financial globalization (De Angelis, 2003).

Taking into account the "purposes" that, according to Boughton, the IMF surveillance currently pursues, the elements that shape the SDR framework at this first moment are introduced below (Boughton, 2014:7).

1) Evaluation of the consistency of policies across countries. In the context of this function, the Fund empirically analyzes the manner in which different states have recently carried out SDR processes.

It is a task of the IMF to spread the specialized knowledge of several of its departments. The data used for the evaluation comes from the supervision missions of article IV or from its financing programs. The last major effort in this regard was made in 2013, the year where the Fund empirically compared the consistency of the restructuring processes of Belize (20072013), Jamaica (2010-2013), Saint Kitts and Nevis (2012), Greece (2012) and Argentina (2005-2010) (IMF, 2013).

With the different analyses made, the IMF assesses the efficiency of its SDR framework, and seeks to prevent the detected errors from being repeated in the future. The diagnoses are reflected in technical reports that are submitted to the Executive Board. If these reports detect significant problems, the diagnoses usually attract the attention of other agents of global financial governance; that is to say, the reports tend to place SDRs at the core of the international political agenda (Manzo, 2019a:12-13). More relevantly, these reports could initiate a reform process such as the one activated by the referred 2013 report (IMF, 2013).

The members of the Fund staff participate in the content design of these reforms, which become new reports that the IMF's political authorities can reject or approve. If they are approved, the Fund develops spread strategies so that the reforms can be actually incorporated into the financial agent practices to prevent future disruptions. Being these reforms of voluntary application -like those mentioned below-, the IMF itself monitors their degree of application and consistency (IMF, 2015; 2017).

2) Advising member states on how to improve their policies. The IMF's shift from a surveillance policy per se to a specific crisis prevention policy was conceived two decades ago with the development of a set of guidelines directed to strengthening the institutional capacities of its member states in order to mitigate their financial risks at the time of operating in a globalized and liberalized system.

The 2001 "sovereign debt" and "international reserves" management guidelines are two clear instances of evidence of such transformation (IMF, 2001; 2001a). Both guidelines were 
the result of a complex consultation process that the IMF conducted with specialized official representatives from different countries. This process enabled the Fund to identify common problems as well as a set of shared principles and behavior patterns. The main recipients of the guidelines are the governments themselves, which may or may not adopt the IMF recommendations. In 2003, the Fund carried out an empirical analysis in 18 countries to especially observe the degree of reception of the guidelines and update them with an Addendum (IMF, 2003; 2003a; 2003b).

The relevance of these guidelines to avoid situations of unsustainability that place a potential SDR on the horizon is essential. This is so because a poor structuring of the international reserves or of a debt portfolio, in terms of maturations, currencies or interest rates, has been throughout history one of the main factors which triggered or spread financial crises (IMF, 2014).

Following these considerations, the guidelines set a series of basic rules so that governments can meet their objectives without assuming an excessive financial risk. In particular, these rules are related to the transparency of debt and reserves management, the responsibility of the authorities involved in said management, the establishment of an appropriate institutional framework and, finally, a careful administration of vulnerabilities and contingencies (IMF, 2003; 2003a; 2003b). The global financial crisis led to the revision of both sets of guidelines in 2013 and 2014, respectively (IMF, 2013a; 2014). The performed changes updated the rules of 2001/3 and specifically recommended the use of Collective Action Clauses (CACs) for SDRs (IMF, 2014:9).

To understand the recommendation, it should be noted that in bonds denominated under New York law - the main financial jurisdiction - these types of clauses were absent in the beginning of the 2000s. Instead, the contracts of these bonds included clauses that, on the one hand, required unanimous consent of creditors when a debtor sought to restructure its debt and, on the other, gave to any of these creditors the possibility of accelerating the payment of the totality of the debt, when the debtor left one of its quotas or parts unpaid (Weidemaier- Gulati, 2013).

These clauses made SDR processes virtually impossible in contexts of large and heterogeneous universes of creditors. In fact, the opposition of only one of them was enough to bring down the whole SDR agreement reached by the debtor state with the other hundreds or thousands of creditors (Guzman-Stiglitz, 2014).

The IMF, along with other leading agents of financial governance, began to recommend in the early 2000s the use of CACs to deal with the problem. These clauses are aimed at organizing the will of the creditors collectively. Specifically, they demand that in a default event, the acceleration of the sovereign debt must be requested by a predetermined percentage of creditors (usually 25\% of the creditor universe) (IMF, 2003d).

Similarly, CACs grant a qualified majority of creditors the possibility of binding the minority to the terms of a given SDR offer, making more difficult for dissident creditors to attack 
the SDR process as a whole. More specifically, CACs allow modification of the original terms of a sovereign debt if the restructuring proposal is supported by a predetermined percentage of the creditor universe (usually 75\%) (IMF, 2014a:16).

The IMF's work in this regard is not limited to recommending the use of CACs, but also to offering standardized models for them. In the first round of SDR reforms (2001-2003), the models were designed to operate "series by series". In sovereign debt contracts, it was stipulated that if a percentage of bondholders of a particular series accepted the debt restructuring offer, the other bondholders of that series should remain tied to the terms of this offer. Then, some countries drafted CACs with "two limbs". These models offer a double voting structure which requires a qualified majority for each particular series on the one hand, and, on the other, for all series to be restructured (IMF, 2014a; Manzo, 2019).

At the time of revising the use of CACs, the 2013 report warned that such models were not fully effective for solving the new collective action problems. Consequently, the Fund, again in collaboration with other leading agents of financial governance, proposed in 2014 a new model of CACs: the so-called "single-limb" procedure (IMF, 2014a:20). We are in the presence of the main innovation of the second round of SDR reforms (2013-2016).

This new procedure requires only one limb to be achieved in future SDRs (in principle, 75\%) calculated on an aggregate basis of all affected bond series (IMF, 2014a:20). However, this procedure does not imply the disappearance of the existing ones nor does it inhibit the possibility of implementing other similar sub-aggregation procedures. What the 2014 reform ultimately does is to grant a "menu" of possible options, which the debtor can use at the time of facing a given restructuring (IMF, 2014a:23). As creditors do not know which of these options the debtor will actually pick, they cannot plan with reasonable anticipation a suitable dissident strategy. Therefore, the reform limits the possibility of altering the global result of a particular SDR process (Manzo, 2019).

In 2014, the Fund also provided a set of subsidiary provisions so that the new models of CACs can properly operate in practice. On the one hand, the IMF offered model clauses which include robust provisions of disaffection. These provisions aim to prevent sovereign debtors from using their authority position within a given market to manipulate the voting procedure (IMF, 2014a:26). On the other hand, the Fund urged the parties to include provisions to make sure that creditors will be provided with timely and adequate information during SDR processes (IMF, 2014a:25 and 31).

More importantly, in 2014 the Fund exhibited new models of "pari passu clauses". Since the end of the 1990s, judges have been using these clauses as sui generis mechanisms to force debtor states to pay sentences owed to dissident creditors (known as "vulture funds" for their particular practices). The IMF, in its new models, advocates for a wording of these clauses that explicitly excludes from the sovereign debt market a dissenting interpretation - the so-called "pro rata" interpretation - which allowed judges to use them precisely as an alternative enforcement mechanism (IMF, 2014a:15). 
3) Transmitting key messages about what is going on to member states and warning them when their policies are off track. ${ }^{\mathbf{8}}$ Over the last two decades, the IMF refined its surveillance tools to increase its capacity to send accurate and duly informed signals to the international community. The purpose behind these signals is to avoid that the factors that make an SDR necessary can be reversed even before they get triggered or combined.

The 2001 and 2002 IMF reports to assess "Market Access" (MAA) and "Debt Sustainability" (DSA) are central parts of this effort (IMF, 2001c; IMF, 2002). These instruments should not be thought of as mere technical tools, but as a complex theoretical-conceptual scaffolding (Schadler, 2016).

MAA and DSA are related but different. DSA mainly aims to evaluate the sovereign debt course and the state fiscal capacity to serve it. MAA is basically directed to ponder the capacity of a state to collect in acceptable terms the necessary financial funds to meet its objectives and obligations. This capacity has an impact on the sustainability of the debt, both through the interest rates and the debt portfolio resulting from the loans taken by a given government. Inversely, doubts about the debt sustainability influence the terms of market access or, in extreme cases, the access itself (Guscina et al., 2017:4).

The concern about MAA arose in the early 2000s as part of the discussions about the "private sector involvement" in times of crisis. The logic of the discussions can be summarized as follows. The IMF has limited resources and assumes great risks when financing a state in an economic distress situation. The possibility that the state overcomes this situation will largely depend on the behavior of private agents. They can collaborate or assume a passive stance during the crisis. Even worse, they can exacerbate it by fleeing their capitals or by using them for speculative businesses. It is essential, therefore, to accurately understand why the agents act in one way or another. MAA is precisely a systematic effort in this direction (IMF, 2001c).

Comparatively, these efforts have not yet reached the operational level of DSA. As Guscina explains, the operationalization of MAA is not an easy task: one thing is to analyze a posteriori why a state lost access to the market and a very different one is to create empirical indicators to anticipate such processes (Guscina et al., 2017:10-11). The Fund is currently halfway between both extremes. Since the beginning of the century, it has made important advances in the former sense, publishing, in addition to the original report, two complementary works in 2001 and 2005 (IMF, 2001b; 2005a). In 2007, the IMF warned about the need to translate these advances into the design of an empirical measuring instrument, but it has not yet completed this task (IMF, 2007).

The lack of such instrument does not mean disregard for the performed work. With a detailed analysis of Loss of Market Access (LMA) cases, the Fund has been able to find

8 On this point, we combine two of the purposes exhibited by Boughton (2014) on pages 6-7. 
regularities concerning these processes. Specifically, it has individualized the factors and determinants by means of which a state: 1) has good access to the market; 2) has lost said access; 3) has recovered it (IMF, 2001c:35-36).

These three dimensions are linked in the IMF's studies. In fact, the modality and speed of the mentioned return to the market depends on the type of relationship that the state maintained before pulling out of it, and on the causes that motivated it. Based on this knowledge, the staff informs the Fund's political authorities about market access of member states annually (article IV surveillance) or with the frequency determined by a financing program (IMF, 2001c:35-36).

The staff also informs about "debt sustainability". Despite the relevance that a hypothetical external observer could attribute to this dimension, the fact is that the literature on economics has not given much importance to it (Schadler, 2016:1). The Fund did not have an adequate framework to analyze debt sustainability until the early 2000s. Before this date, the IMF indirectly performed the analysis taking three aspects into consideration: global external sustainability, fiscal sustainability, and financial sector sustainability (IMF, 2002:7).

Analyzing how specialized private agents measured sustainability, in 2002 the Fund approved a comprehensive framework aimed at addressing it with greater discipline and consistency (IMF, 2002:24). ${ }^{9}$ In 2003 and 2005, the IMF evaluated the framework application and improved some aspects of the original proposal (IMF, 2003e; 2005). In 2005, along with the World Bank, the IMF specified DSA for Low Income Countries (LIC). Since then, there have been two differentiated modalities of the framework: one for LICs and another for countries which, in normal circumstances, have access to the market (IMF, 2019). Similarly, in the latter modality, the IMF differentiated between emerging countries and advanced economies (Rieger, 2018).

The differentiation became relevant after the global crisis of 2008. The crisis made visible the high level of indebtedness of advanced economies and led the IMF to update DSA in 2011 (IMF, 2011). Two years later, the Fund produced guidelines to orient the staff practices when having to conduct the analysis. The guidelines represent a real effort to operationalize the concepts of DSA, following empirical indicators (IMF, 2013b). Finally, in 2014 the IMF published DSA "templates" to easily identify the criteria to be considered at the moment of interpreting the decisions made and based on this instrument (IMF, 2018).

The 2011 DSA reform implemented the so-called "risk-based approach". The approach considers that the depth and extent of the scrutiny that a country should be subject to depend on the degree of sustainability of its debt: basically, the higher the level of unsustainability

9 This comprehensive framework, within which DSA is located, is called "Debt Sustainability Framework" (DSF). 
risk, the greater the vigilance, and inversely, the lower the level, the lesser the vigilance (IMF, 2013b:5). More accurately, the approach establishes a series of objective indicators (an " $x$ " percentage of debt/GDP ratio and of financing necessity/GDP ratio, or the demand for exceptional access to the Fund's resources) to determine whether a state should be subject to "low" or "high" scrutiny.

If the state is considered of "low" scrutiny, the IMF conducts a "basic DSA". This DSA includes, initially, a panorama of the data of the country's debt in current time; in other words, tracing the course, the Fund shows the debt structure based on a set of indicators aimed at exhibiting the debt weight on the economy and its composition in terms of, for example, currencies and maturations. Then, the IMF forwards the future through a series of debt projections. First, it performs a baseline projection, considering the evolution of the addressed indicators in a scenario characterized by the continuity of the present course. Secondly, it makes projections for alternative scenarios (IMF, 2013b:5).

If the state is considered of "high" scrutiny, the Fund carries out a more complex DSA. This DSA involves, in addition to the basic elements, a "risk identification and analysis" by means of which the IMF tests the realism of the baseline scenario, the vulnerability of the debt profile, the sensitivity of the macro-fiscal risks and the contingent liabilities. The staff presentation of the analysis is more demanding and must include heat maps and certain charts (IMF, 2013b:5).

The Fund is aware that the data emerging from these instruments only do not mean much and should be interpreted. Consequently, the IMF reports provide guidelines to orient the task. The general rule in this sense is to avoid mechanical or rigid interpretations that leave aside the particular circumstances of the scrutinized country (IMF, 2003e:43-44).

At the stage of prevention, both MAA and DSA use the information collected by article IV consultations. Between 6 and 3 months before a consultation takes place, staff members of several IMF departments begin an internal examination of the state to be evaluated. The examination ends with a "guidance note" that is submitted to the Managing Director for approval. The document details the fundamental issues to be considered in the consultation, which is materialized when an IMF team is sent on a "mission" to the country in question. On this mission, the team collects detailed information about the state's economy and meets with senior government officials as well as with other key interlocutors (IMF, 2017a; 2016).

When the mission is back, staff members write specific reports about the country and, in the frame of the so-called "multilateral surveillance", about the regional or global economy. Once concluded, the reports are submitted to the Managing Director and then to the Executive Board for approval. The Board's evaluation and the reports themselves are transmitted to the consulted state and, with its consent, made publicly known in the press (IMF, 2017a; 2016).

It is precisely via these reports that the Fund sends key messages to the international community. The reports inform about what is going on in the member states economies and 
give warning when they consider that their policies are off track. Generally, the IMF goes further by recommending that the involved government makes changes in its policies in order to prevent the observed problem from turning worse, eventually affecting debt sustainability. In the following mission, the Fund controls the degree of adequacy of the government to the preceding warnings or recommendations. ${ }^{10}$

The implied messages are sustained by the information provided by DSA and MAA. In individual reports, the weight of DSA is greater than that of MAA. ${ }^{11}$ Only DSA is included as an autonomous section in the annexes of the reports. Based on this section, the IMF explains the debt situation in the body of the text, usually at the time of introducing the fiscal dimension of the evaluated economy. In the fiscal dimension, MAA is also included. The analysis shows the way in which the state plans to access the market and stress what would happen if access conditions change. ${ }^{12}$

Finally, it is essential to note that these messages - warnings and recommendations - are not mandatory for the consulted country. In this sense, the effectiveness of the Fund's surveillance role to prevent an unsustainable accumulation of debt will ultimately depend on the adequate use that debtors and creditors make of the messages (Riegner, 2016).

\section{FinANCIAL CRISIS MANAGEMENT: PREPARING AN SDR IN LIGHT OF THE IMF} LENDING POLICY

The second moment of analysis takes us to a scenario in which the state has fallen into an economic distress situation and the possibility of conducting an SDR process appears on the horizon. If this is the case, the IMF plays a key role in defining when, how and how much of the SDR will be implemented by means of its "financing function".

For some decades already, this function - and no longer surveillance - is the backbone of the Fund's work (Boughton, 2014:5). Originally, the IMF was designed as an independent multilateral lender that granted temporary loans to states with balance of payments problems. The Articles of Agreement, as Boughton and Horsefield explain, prohibited the financing of "large and sustained outflow of capital" (Boughton et al., 2014:2; Horsefield 1969: 403).

10 For example, see DSA for Argentina on pages 68-79 and 64-75 of the Article IV Consultations of 2016 and 2017, respectively. (IMF, 2016; 2017b).

11 The weight of DSA is greater in the reports than that of MAA because of its greater degree of operationalization and different orientation (MAA framework is more oriented to the resolution than to the prevention of crisis).

12 For example, see the IMF reports for Argentina (IMF, 2016; 2017b). 
However, in the 1960s the Fund began to apply such practice. Following this trend, in the 1980s the IMF was able to transfer, individually or in coordination with other financial agents, huge amounts of resources over to those countries facing an external debt crisis. Since then, the Fund has been operating de facto as a sort of "global lender of last resort" (Gelpern, 2014).

At this point, it is convenient to make clear that states can conduct SDRs without the IMF assistance. This is so because there is no international rule that ensures the participation of the global community in this kind of event (Manzo, 2018:27). Even in these cases, the Fund can influence SDRs by making use of the briefly described surveillance tools. In fact, when a country's debt is defined by the Fund as “unsustainable”, investors tend to discontinue their financial support and, even worse, to flee their capital out of the affected economy. Therefore, the unsustainability declaration exercises influence on a government's decision to initiate an SDR. Inversely, in the absence of such declaration, creditors, especially in predefault scenarios, can judge the activation of this process as unnecessary and, therefore, refrain from participating in it (Manzo, 2019).

It may also occur that the IMF finances a state which does not activate an SDR. In fact, this is the ordinary case, since SDRs have always been considered by the Fund as "ultima ratio" processes. When a state is faced with an economic distress situation, the adjustment of the economic policy and the Fund financing - the 2013 report states - is expected to cause a "catalytic effect" on private lenders, who will spontaneously provide resources contributing to solve the balance of payments problems. In such cases, the state retains its capacity to serve the debt in accordance with the original terms and, therefore, it is not necessary to restructure it (IMF, 2013:7).

However, there are circumstances where the described logic is not a priori viable. The difficulties of a state to easily access the market and an excessive level of indebtedness appear as warning signals in this sense. When a state requests financial support in this context, the IMF's influence on the preparation of a possible SDR event is increased. This influence is exercised, as seen below, following the conditions that the Fund establishes to access its resources.

1) Normal and exceptional access to IMF resources. In 1983, the Fund's Executive Board approved the guidelines for lending access. Basically, any member state that demonstrates the need for such resources and the capacity to, on the one hand, return them in a timely manner and, on the other, implement an economic policy program consistent with the IMF's orientation could count on its financing (IMF, 2003f:3).

In 1992, the Fund defined a framework to assess the financial amount that each member state could request. This - known as "access limits" framework - established that such amount would be determined by three circumstantial indicators (the balance of payments gap, the repayment capacity and the level and history of indebtedness with the Fund) and a general indicator, relative to a percentage of the state's quota with the IMF. Thus, for example, in the 
1990s an annual access limit of $100 \%$ of the quota and a cumulative of $300 \%$ of it was set (IMF, 2003f:3-4).

Paradoxically, the recent history of SDRs in the IMF has been inextricably linked to the granting of credits that exceeded those limits. In the 1980s, access to exceptional amounts or, simply, "exceptional access" to the Fund resources rarely occurred (IMF, 2014b:9).

With the Tequila Crisis, the situation changed. From 1995 to 2002, the IMF granted 14 credits above its normal financing limits, some of them of unprecedented amounts (IMF, 2014b:9; 2002a:33). Although the quantity of exceptional credits represented a relatively small percentage of the total number of the credit universe, the fact is that, because of their volume, it was in these cases that the Fund concentrated the largest credit exposure (IMF, 2014b:8-9).

Consequently, in the end of the $20^{\text {th }}$ century, the $G 7$ countries started an intense debate about the significance of such credits. The position that finally prevailed at the IMF was that which accepted that not all crises could be averted by means of financial bailouts. Furthermore, in certain circumstances the bailouts increased the cost for most of the good-faith players affected by the economic distress situation (Schadler, 2015).

Based on this diagnosis, it was then seen that the current framework was too permissive to allow exceptional access to Fund financing. Indeed, until 2002, in order to have access, it was sufficient to invoke "exceptional circumstances" or request it by means of alternative credit lines to which the established normal limits did not apply (IMF, 2002a:4).

Hence, actions to modify the framework were initiated in 2001 ; they certainly impacted the way in which SDRs were organized (IMF, 2002a). In 2009, after the global financial crisis, the exceptional access framework was modified - (IMF, 2009) - and in 2016 it was part of the reform program activated by the 2013 report (IMF, 2014b; 2015a; 2016a).

Basically, since 2002 four criteria have regulated exceptional access. ${ }^{13}$ The first criterion refers to the requirement of proving the existence of financial imbalances of such magnitude that there was the need for an amount of IMF financing exceeding the normal limits. The fourth criterion is linked to the policy program that accompanies such financing: the program, in accordance with this criterion, should have a reasonably sound perspective of being implemented and of complying with the macro-economic goals (IMF, 2015a).

The second and third criteria are directly related to SDRs. Indeed, IMF large loans will only be granted to a member state after a rigorous analysis of the debt sustainability (second criterion) and the possibilities of access to private sector financing (third criterion). In practice, the analysis is carried out precisely through DSA and MAA introduced in the preceding section (IMF, 2015a). 
In light of these last two criteria appear two typical-ideal cases: one of them where the IMF provides exceptional access to its resources and the other where a priori it does not. The former case occurs when the Fund concludes that the debt of the requesting state is "sustainable with high probability" and the loss of market access that it suffers is "temporary". The latter situation occurs as the opposite case. That is to say, when the sovereign debt is not judged clearly sustainable or when there is no certain possibility that in the short term the state will re-access the market or, more technically, during the term in which its debts with the Fund remain outstanding (IMF, 2015a).

In the latter case, the IMF grants financing on the condition that the debtor state implements a "prompt" and "definitive" SDR. We are here in the presence of a fundamental perspective change which must be noted. In fact, from the mid-1970s to 2002, with the exception of the Brady Plan, the Fund's bailouts essentially sought to avoid SDRs; since 2002, the bailouts have been subordinated to the occurrence of one restructuring process. This shift was based on the already mentioned conception: the resources provided to the state in the described circumstances would not be enough to reach the intended purposes and, on the contrary, would encourage speculative operations (IMF, 2015a).

In the 2016 reform, a new typical-ideal case was added. The aggregated case sought to address one of the main limitations observed by the IMF: the analyzed SDRs - the 2013 report had concluded - usually arrived "too late" to restore debt sustainability and market access in a lasting manner (IMF, 2013:7). Consequently, the reform provided a different solution to those intermediate cases in which the requesting state has temporarily lost market access and its debt is deemed "sustainable, but not with high probability" (IMF, 2016a).

In such cases, the IMF grants exceptional access if and only if the debtor state promptly activates a debt "rescheduling" process. That is to say, if it activates a smooth restructuring aimed at extending the terms of the debt with imminent expiration, without reducing its principal or interest. In these circumstances, the IMF decides to assume a larger financial risk in order to give a quick response, in the assumption that waiting for a state to implement a definitive SDR would be more costly to the majority of the involved agents (IMF, 2016a:4).

It is relevant to clearly state that in these cases there can also be a scenario where the IMF grants resources without the need of debt rescheduling. This is the case when other official creditors commit themselves to finance the requesting state during the term of the Fund program. This is so because this additional financing essentially plays the same role as the said rescheduling would: it allows the state to pay the debt by means of acquiring further debt in conditions relatively more favorable than its current situation (this operation is called "roll over") (IMF, 2016a:4-5).

Finally, it should be noted that these official sector commitments do not inhibit the application of the third criterion of the exceptional access framework; that is to say, the criterion that conditions such access to a certain perspective of market access. The clarification makes 
sense here, because it was a central point of discussion during the 2016 reform process. The position that finally prevailed postulates that the financing of the official sector does not replace that of the private sector. From the IMF perspective, the resolution of the balance of payment problems and the external viability can be achieved in the medium term if and only if the state is able to access resources of the latter sector (IMF, 2016a:7).

2) Access to IMF resources in circumstances of arrears. There are occasions where the economic distress situation is of such magnitude that debtor states simply cannot face the payment of their debts, and, consequently, incur in default.

At the dawn of the financial globalization age, the Fund authorities debated what to do with a financing request under these conditions. The position that prevailed since 1970 has been known as "no-tolerance policy". At the center of this policy appeared the principle of not providing financial support to those debtors that held debts in arrears with their creditors, or merely the "principle of not lending into arrears" (IMF, 2015b:6; Simpson, 2006:10).

The policy, of course, sought to deter possible defaults. Avoiding a default - the 2013 report states - "is important not only because it may exacerbate the immediate economic and financial dislocation, but also because it may undermine the member's capacity to reaccess international private capital in the medium term" (IMF, 2013:11).

Following this position, the Fund also saw such capacity as a key element to safeguard its own resources. This is so as long as the probability that the state repays the loans largely depends on market re-access (IMF, 2015b:6).

In a similar way, the no-tolerance policy was directly related to SDRs. With it, the IMF intended to encourage the parties to start negotiations directed to finding a solution to their common problem; such solution could imply a debt restructuring. The expectation of having the Fund's resources - it was thought - would delay the beginning of such negotiations (Simpson, 2006:9). In this direction, it is relevant to note that the new IMF policy did not imply that at the time of approving the program there were no debts into arrears. It was sufficient, for this purpose, that the requesting state and its creditors had reached an agreement in order to deal with the arrears (IMF, 1999:3).

In the mid-1970s, the Fund began participation in these negotiations (Boughton et al., 2014:3). During the following years, its credits were granted in practice if there was a commitment to clear the arrears within the term of the program (IMF, 2015b:6). By the end of the decade, most of the letters through which the states requested the financing - called "Letters of Intent" - included the commitment to make regular payments to private creditors. This meant a relevant change given the fact that, in the previous decades, there was no mention in the letters of the form of payment of the sovereign debt (Babb \& Buira, 2004:8).

In the 1980 s this trend was maintained. Over those years, almost $80 \%$ of the Letters of Intent of the states that were facing an external debt crisis established the conditionality 
that the involved government would be committed not to incur in arrears (Babb \& Buira, 2004:8-9).

The IMF supported the programs approved in said letters with large financial packages. The currencies that composed them were jointly contributed by official and private sector agents through "concerted credits" with the Fund (Boughton et al., 2014:3) The debtor state used the resources to pay the debts and clear its arrears (roll over). Eventually, private creditors - mostly, large commercial banks - agreed to refinance their credits, but there were no reductions of the principal or interests (Boughton et al., 2014; Simpson, 2006).

In the late 1980s, the IMF strategy to deal with the crisis triggered tensions with those creditors. The incentives to participate in concerted credits or conduct other types of concessions to debtor states were, throughout the decade, diminished as their financial situation was being cleared. In this scenario, the no-tolerance policy gave the creditors a sort of "veto power" over the Fund's lending decisions (IMF, 2015b:7).

In fact, these decisions depended on the creditors' support for an agreement with the requesting state to clean up the arrears, a support that now some of them were not willing to grant. The issue was that those states were still facing deep economic imbalances and resorted to the IMF precisely because they lacked the necessary resources to pay their debts (Boughton et al., 2014:4; Simpson, 2006:3).

In such circumstances, in 1989 the Fund modified its policy. In future, the IMF would tolerate arrears with commercial banks during the term of the programs under the condition that financing be considered essential for the success of the adjustment program, that the state's negotiations with creditors had already begun and that a financial package consistent with the external viability was agreed on within a reasonable period (IMF, 2002b:3).

This new "Lending into Arrears" (LIA) policy did not mean the disappearance of the IMF no-tolerance policy for official creditors. Thus, in 1989, the Fund's manner of addressing the arrears was divided into two relatively differentiated frameworks: one related to the new LIA policy for private creditors and the other linked to the continuity of the no-tolerance for official creditors (IMF, 1989).

That year, the IMF Executive Board justified this differentiation by pointing out that official creditors did not provide financial support only to obtain profits, but also for public policy reasons. Consequently, they were the ones who generally financed states when private investors were no longer willing to do so. Then, according to the logic of the Fund, the differential treatment between one and the other type of creditors was consistent with its dominant conception of dealing with crises by means of large bailouts (IMF, 2015b:8).

In 1998, the IMF expanded the universe of private creditors reached by the LIA policy to "bondholders". The expansion sought to reflect the changes occurred in the last decade in the composition of international capital flows and, in particular, the increasing securitization of sovereign debt (IMF, 1999). 
The following year, the Fund again updated the LIA policy. Considering that in this new scenario states would have greater difficulties to restructure their debts, the IMF softened the policy requirements. Instead of conditioning financing when the debtor had effectively initiated negotiations to clear the arrears, now it was enough that it made "good-faith efforts" to reach a collaborative agreement with its creditors (IMF, 2002b). In 2002, the Fund introduced a set of principles to interpret this last criterion (IMF, 2002b).

Also, in 2015 the IMF relaxed the no-tolerance policy giving way to a new "LIA policy for official creditors" (IMF, 2015b). This flexibility sought to respond to another of the limitations observed in the 2013 report. ${ }^{14}$ In particular, that report had considered that in recent SDRs the no-tolerance policy had not been properly adapted to the new reality of this group of creditors, which were no longer limited to the traditional ones from the G7 countries (IMF, 2013:7).

Following practices already in force, the new 2015 framework interpreted that the arrears with creditors of the Paris Club were considered resolved if the member state had reached an appropriately representative agreement with them. If such agreement had not been reached, the Fund could also finance said state despite its arrears with official bilateral creditors under certain circumstances. In particular, the IMF would do so if its financing was considered fundamental, if the member was developing adequate policies and good-faith efforts to reach an agreement, and finally if the Fund's decision to lend into arrears did not have in the future a negative impact on its capacity to use official financial packages (IMF, 2013).

In sum, the LIA policy consolidated the Fund's role in SDRs. This policy allowed it to formally participate in these processes, even if the debtor state was already in default. We have analyzed rather in detail the historical evolution. As shown in the last section, since 2002 the specialized literature considers LIA as the IMF policy for SDRs.

3) The design of the restructuring plan in light of the IMF programs. The Fund's influence on the design of the restructuring plan - that is, on the decisions about when, how and how much debt should be restructured - is implemented and organized by means of the "financing programs". These programs provide the means for the Fund to make operative its lending policy in specific cases. In this case, the "conditionalities" that are incorporated play a central role.

In SDRs, the conditionalities are often thought of as the sacrifice that a debtor state must make in compensation for the effort that the international community makes to help it overcome the crisis (Díaz-Cassou et al, 2008:12). More specifically, the conditionalities are the instruments through which said state formally commits itself to adopt a determined set of policies in order to access the Fund's resources (Buira, 2003:3).

14 The 2013 IMF report also observed limitations in the way in which the LIA policy was implemented in the latest SDRs. However, the reforms to overcome said limitations have not yet been completed (IMF, 2013:7). 
Originally, these resources were granted without any conditionality. The situation changed in 1952, when the so-called "stand-by credits" appeared. During the following two decades, the IMF conditionality policy operated under the legal coverage of these credits, and in 1969 said policy acquired statutory character, when it was incorporated into article $\mathrm{V}$ of the Articles of Agreement (Buira, 2003:5-7).

In the corresponding programs, references to sovereign debt appeared in the 1960s in terms of "debt limits": in fact, credits were granted if and only if the debtor state committed itself to not increase the debt beyond a given limit. ${ }^{15}$ As it is widely known, in the 1970 s these references increased with the no-tolerance policy and the commitment of states to not incur in arrears with creditors (Babb \& Buira, 2004:8).

In 1979 , the IMF organized the conditionality policy following guidelines specifically written for this purpose (IMF, 1979). This reform increased the Fund's ability to influence the debtor state policy by extending the duration of the stand-by credits from one to three years (IMF, 1979:1). It also defined the "modalities" that conditionalities could assume in a given program and their impact on the disbursement of the agreed resources during the different credit sections (IMF, 1979).

The external debt crisis greatly expanded the number and impact of the Fund conditionalities. Until the 1980s, they were focused on temporary and limited variables, while later they were aimed at producing transformations in the economic structure of the debtor state (Badd-Buira, 2004:9). These "structural conditionalities" acquired a relevant role in the IMF lending policy, reaching their peak in the late 1990s when the programs included several dozens of them (Badd-Buira, 2004:12). In this context, the reforms of 2002 - (IMF, 2002c; 2002d) - and 2009 - (IMF, 2009; 2009d) - were directed to reduce the number of conditionalities, limiting them to the core of the Fund's mandates and preventing their non-compliance from blocking the disbursement of funds.

Formally, states are the "owners" of the programs and, consequently, of the design of the restructuring plan. ${ }^{16}$ However, the documents - Letter of Intent and complementary Memoranda - that give content to said programs are written by states in cooperation with and with the assistance of the IMF staff. ${ }^{17}$ Also, of course, these documents must respect the

15 Currently, this conditionality has been improved with the establishment of a framework to determine the type of limit that corresponds to the degree of debt sustainability (IMF, 2014c; 2015c).

16 Point 3, "Ownership and capacity to implement programs", of the "Guidelines on Conditionality" (IMF, 2002d).

17 Point 10, "Members program documents", of the "Guidelines on Conditionality" (IMF, 2002d). Also, for an example of these documents, see IMF, "Argentina Letter of Intent”, "Argentina Memorandum of Economic and Financial Policies” and "Argentina Technical Memorandum of Understanding” (IMF, 2018c). 
Fund's orientation and frameworks. Indeed, once a program is submitted, the staff prepares a detailed report of the financial situation of the requesting state, showing whether its financing request meets the requirements of the lending policy. ${ }^{18}$ The IMF Managing Director brings the program before the Executive Board for its approval and, once approved, it is published in the press. ${ }^{19}$

Following the former considerations, it should be noted that the Fund influences the decision on when to restructure a sovereign debt as follows.

Ideally, an SDR process supported by an IMF program should be activated "before" its approval. However, there may be situations in which greater flexibility is necessary. In such cases, there can be programs activated before the SDR beginning, but setting as a condition that the steps necessary to perform such activation be carried out within a certain period. In this way, the IMF avoids the delay in granting its funds, with the aim of preventing a possible worsening of the crisis (IMF, 2016a:5).

In this scenario, DSA is usually presented as the "trigger" of SDRs (Buchheit et al., 2018:4). While the decision on when to start this kind of process is always a political decision of the debtor state, the fact is that the IMF's opinion in this regard certainly has an influence on it. This opinion is not based exclusively on DSA (Gelpern, 2014:25). In order to make a recommendation, the Fund takes into account an amount of information that also comes from other sources of analysis (IMF, 2016a:7). However, DSA is the specific instrument for this purpose. This is so, as already noted, because in the IMF conceptual framework the activation of SDRs is inextricably linked to the notion of debt "unsustainability". ${ }^{20}$

This notion allows the Fund to recommend such activation in three different time contexts. The IMF recommends an SDR: firstly, "preemptively" in contexts in which the debt is "sustainable, but not with high probability", and secondly, "definitively" when the debt becomes "unsustainable with high probability" (pre-default scenario). It also proposes a "definitive" SDR when the state already incurred in arrears (post-default scenario). In all the mentioned contexts, the IMF suggests that the debtor initiate the process the sooner the better, and use its resources as an incentive to this end (IMF, 2016a; 2002b).

The Fund also influences how to restructure a given debt. The information provided by way of DSA and MAA is usually the essential input at the time of deciding which debt should be included in the SDR process (e.g. internal or external debt) (IMF, 2011). Particularly

18 For example, see IMF, “Argentina Request for Stand-By Arrangement” (IMF, $2018 \mathrm{~b})$.

19 For example, see "IMF Executive Board Approves US\$50 Billion Stand-By Arrangement for Argentina" (IMF, 2018a).

20 Pedagogically, it is often pointed out that the notion of unsustainability in SDRs plays a role similar to that of insolvency in corporate bankruptcies, but this statement is not entirely correct (Bolton, 2003:57). 
in intermediate cases, it suggests that maturing debts enter into rescheduling (IMF, 2016a:5). Similarly, the IMF participation in the program drafting and its support to collaborative creditors tend to influence the government's choice of the SDR strategy and instruments (IMF, 2002b:5).

Finally, the IMF influences how much debt to restructure with its fiscal and monetary conditionalities. It should be noted that since the mid-1970s -years in which the Fund embraced neoliberalist intellectual currents- the so-called "austerity policies" have been at the center of the programs (Badd-Buira, 2004:21). These programs stipulate fiscal and monetary adjustments that ultimately determine how many of its own resources the state could destine to the payment of the debt during a certain period.

The total amount of resources directed to the payment of said debt is completed in that period by adding to these fiscal resources those others resources, on the one hand, agreed with the IMF and, on the other, projected by the official and private sector financing, according to the prospects of market access. The gap between the sum of all these resources and the amount of debt maturities that the state must effectively meet during that period determines, in the IMF conceptual framework, the amount of debt to be restructured (Gelpern, 2014:25; Haley, 2014:7).

The Fund expects the SDR to be of such magnitude that, after the process, the debt becomes again "sustainable with high probability" (IMF, 2015a). The IMF understands that if the SDR has not been reached in depth, the relief to the distressed economy would be only temporary and would surely incur in new imbalances; that is to say, the SDR would not be "definitive". This was precisely what happened in many of the analyzed SDRs which, according to the 2013 report, were "too little" ("too little and too late") (IMF, 2013:7).

Finally, it should be noted that in order to achieve this result, the Fund does not in all cases propose a capital or interest "reduction". In fact, historically, the IMF opposed this kind of relief. ${ }^{21}$ Currently, it proposes this relief when it considers that the debtor state using the jargon of corporate bankruptcies - is "insolvent" (IMF, 2013:8). On the contrary, when the Fund believes that the state only faces an "illiquidity" problem, it recommends a debt "refinancing" (IMF, 2013:8). The "rescheduling", a specificity of this last kind of relief, is the only category in which the Fund is willing - for celerity reasons - to grant resources even without having a high probability whether or not the process will return the restructured debt to its sustainability path ("preemptive” SDR) (IMF, 2016a:7).

21 During the external debt crisis and until the 1989 Brady Plan, the IMF did not accept debt reductions. It recommended strong debtor adjustments, but little debt reliefs. Consequently, in the end of the decade, creditor banks had a healthy financial position, while states remained in crisis (Boughton et al., 2014:4; Simpson, 2006:11). 


\section{FinANCiAl CRises resolution: IMF ROLES DURING A SOVEREIGN DEBT RESTRUCTURING}

The third moment of analysis places a scenario in which the state has initiated an SDR with the support of an IMF program. ${ }^{22}$ In this scenario, the Fund is a de facto arbitrator and, as such, it coordinates the roles of all the other involved agents (Gelpern, 2014:23).

Those roles of the Fund were the result of a complex historical process that began with the fall of the Bretton Woods agreement in 1971. The changes in the IMF that occurred during the 1970s, with respect to its greater presence and surveillance/financing capacity in economic distress situations, positioned it, in the early 1980s, as the international actor to face the external debt crisis (Boughton, 2001).

The extension of this crisis effectively led the main stockholders to delegate to the Fund the power to intervene in the affected countries. Lee refers to this delegation process in terms of a real "concertation of powers" between the G7 countries, in order to highlight that it was not the result of the exclusive will of the United States (Lee, 2012:115).

The concern that motivated such delegation was related to how to collect debts from debtors that -due to their sovereign nature- were legally immune to the collection mechanisms applicable to private agents. In this context, the health of the financial systems of the G7 countries depended on the successful resolution of this concern, since the creditors mostly affected by the crisis were precisely the main commercial banks settled in their territories (Gelpern, 2016:48).

The counterpart to this concertation process was the isolation of the debtor states which, at that time, sought to form a common front of debt negotiation (Navarrete, 1985). This isolation was legitimized in the IMF discourse, saying that the circumstances of each state were unique, so that a particular solution corresponded to each case. For debtors, the attractiveness of this strategy - precisely known as case by case - lay on the possibility of receiving large rescue packages in moments of great financial needs (Boughton, 2001).

The collection of these packages by means of concerted credits modified the type of relationship between creditors and the Fund. Indeed, while in the 1970s this relationship was described by Boughton as "of mutual and beneficial dependence" (Boughton, 2001:275), in the 1980s it represented a real coordination of joint activities. To this result contributed the creation, requested by the IMF, of an Advisory Committee that during the crisis operated as the representative agent of creditor banks (Manzo, 2018:18).

Following these considerations, the Fund became, for deeply indebted countries, the entrance gate to international financial markets. As Gelpern explains, since the 1980s the SDR

22 In this section, an SDR is not limited to the specific process of the financial operation of issuance and purchase of restructured bonds, which usually lasts a very short time. Instead, we holistically conceive the process including the decision to start and conclude it with said purchase. 
regime was thought to operate as a "modular" regime, so that each creditor group would be activated sequentially. In fact, debtors ideally could not negotiate with their private creditors if they had not previously negotiated an agreement with the Paris Club and, in turn, they could not do so with this Club if they had not already arranged it with the Fund (Gelpern, 2016:54). The IMF agreement also reinforced the articulation among the different creditor groups: indeed, the resources they provided to rescue the debtor were coordinated by the IMF, so that ideally their disbursements were conditioned to the progress of the negotiations or to the payment of each of these groups (Badd-Buira, 2004:14).

The concern about how to collect a debt from a sovereign debtor found an answer in this new financial crisis governance articulated by the Fund (Manzo, 2018:15-23). In the end of the 1990s, the structural basis that sustained this governance started to be tensioned when the universe of agents acting in this field changed. The shift from a market led by direct financing contracts in the 1970s to one of sovereign bonds in the 1990s implied the emergence of a multiplicity of new agents with different structures and logic. Their coordination entailed a complex challenge for the IMF (Manzo, 2018:21).

From an institutional point of view, this challenge was addressed through the mentioned SDR reforms of 2001/3 and 2013/6. The roles that these reforms assigned to the Fund in the development of these processes are introduced below in two different sections, considering whether the debtor state has or has not incurred in default.

1) Basic rules of the IMF's participation during SDRs. After conducting a comparative analysis of state bankruptcy laws, Bolton polarizes positions in order to show the existence of two typical-ideal systems: one in which the debtor maintains the control of its corporation during the restructuring process - known as a "debtor in possession" - and the other in which the law transfers it to a fiduciary agent or similar. In both systems, the administration is exercised under the supervision of a court and following the guidelines authorized by the specific legislation (Bolton, 2003:45).

These ideal systems cannot be simply transferred to the sovereign field. Given that the debtor is a state, the government necessarily remains in the possession of its national authorities (Bolton, 2003:57). However, and similarly to what occurs in corporate bankruptcies, during the SDR process the debtor must comply with the IMF's conditionalities. In other words, the state government is exercised under the supervision of the Fund and respecting a priori the parameters opportunely negotiated in the program (IMF, 2002d).

The IMF performs this supervision by means of "reviews". ${ }^{23}$ They are made operative by staff missions to the debtor state territory in order to obtain information about the 
economy and policies implemented in a given period. In principle, the reviews are activated every six months, but they can be agreed on with a different frequency. Upon their return, the staff members write a detailed report about the financial-economic situation of the supervised country and the political decisions made by the government. This report is submitted to the IMF Executive Board, which evaluates whether the program is on track or modifications are required. ${ }^{24}$

This evaluation is carried out following the content of the program. In this sense, the program operates as a real frame of reference, so that its proper drafting is essential for subsequent control. ${ }^{25}$ The Fund's guidelines warn in this case that conditionalities must, on the one hand, be clearly differentiated from the rest of the program elements and specified with the greatest possible detail ${ }^{26}$ and, on the other, set compliance deadlines associated with the financing disbursement tranches. That is to say, in practice IMF resources are sequentially conceded, and in accordance with the effective compliance of the stipulated conditionalities. ${ }^{\mathbf{2 7}}$

More specifically, the way in which these conditionalities impact the disbursements depends on the "modalities" which have been assumed. In fact, the conditionalities may have been incorporated as "prior actions" into the program's approval, the compliance with them being an indicator of the debtor's ability to implement the agreed policies. ${ }^{\mathbf{2 8}}$ They can also assume the form of "quantitative criteria", "indicative goals" or "structural benchmarks". While in the first modality the conditionality is introduced so that it allows a particular objective type of control, in the other two - being qualitative - the evaluator is given a larger margin of discretion. ${ }^{29}$ That is why not meeting a quantitative criterion may itself interrupt the continuity of the program, unless the Executive Board decides to grant it a "formal waiver". ${ }^{30}$

The program continuity usually impacts the SDR development, since, as it has already been noted, granting the approved financing depends on it. In a corporate restructuring, the court's declaration concerning the beginning of the event is essential because it formally suspends collection of the debts owed by the company, and allows it to take new credits. Considering the

Point 11 "c": "Reviews" (IMF 2002d). For example, see IMF, "First review under the stand-by arrangement" (IMF, 2018f).

Point 11 “c” “(i)”: "Program Reviews” (IMF 2002d).

Point 11 "c" "(i)": "Program Reviews" and point 10: "Members Program Documents" (IMF 2002d).

27 Point 13: "Floating tranches" (IMF 2002d).

28 Point 11 "a": "Prior actions" (IMF 2002d).

29 Point 11 "b": "Performance Criteria" and "d": Other Variables and Measures (IMF 2002d).

Point 12: "Waivers" (IMF 2002d). 
difficulties that the company may be going through, such measures are deemed necessary for its very survival. So much so, that these new credits - "Debtor-in-Possession" (DIP) financing - are usually granted by the creditors themselves in order to preserve the value of the company and prevent any possibility of not collecting the debt at all (Bolton, 2003).

Although risky, the creditors' decision is not irrational, since the new loans enjoy "priority". Some prestigious authors argue that it is precisely in this feature that the main function and raison d'être of bankruptcy legislation is found. Without preferences - that is, without the possibility of recovering what was contributed before the rest of the creditor universe - hardly anyone would be willing to finance a company that expressly acknowledges not being in condition to honor its debts (Bolton, 2003:63-64).

In the sovereign sphere, IMF financing is usually associated with DIP (Simpson, 2006:9). Nevertheless, as Bolton explains, these notions differ because a DIP is inextricably linked to a restructuring process, while IMF financing is not linked to an SDR; it is granted as part of a more general program (Bolton, 2003:64). In this sphere, financing is - in the Fund's words - also "considered essential to help limit the scale of economic dislocation and preserve the economic value of investors' claims" (IMF, 2002b:2).

Formally, in this field there are no prescriptions similar to those of bankruptcy legislations, which establish an order of priority in the collection of the different types of credits. However, IMF credits are in fact privileged credits (Schadler, 2014:28). This preference is a sociologically institutionalized rule, about which there are only indirect references in the Fund's documents. ${ }^{31}$

In a similar manner, the no-tolerance policy of arrears towards official creditors - partially set aside in 2015 - grants them preferential treatment with respect to private creditors. Finally, it is quite common for contracts to include pari passu clauses that seek to guarantee the same priority treatment for different types of bondholders. Nevertheless, these rules do not apply to the entire debt universe, nor do they have the same degree of coherence and effectiveness as the priority orders of corporate legislations (Bolton, 2003:63).

Additionally, the IMF plays a relevant role as "information provider" in SDRs (Díaz-Cassou, 2008:27). This role is important in these cases, considering the high degree of uncertainty that they often show. In this sense, the Fund points out that "to ensure a high participation [in a given SDR] it is important that the sovereign debtor provide the creditors with adequate information prior to making a restructuring offer (IMF, 2014a:31)”.

Although the IMF does not have a fully consistent framework to regulate this role (DíazCassou, 2008:27), its policy of publishing programs and reviews tends to be in itself a

31 For example, the IMF (2016a:2) report stated: "From the perspective of creditors, the replacement of maturing private sector claims with official claims, in particular Fund credit, will effectively result in the subordination of remaining private sector claims in the event of a restructuring”. 
considerable input in this respect. This is so because in such publications the Fund shows the economic circumstances that led the debtor to restructure its debt, and the political program designed to reverse them. It is relevant to mention that the state can oppose the publication of this information (IMF, 2016).

Then, at the request of the creditor's representatives, in 2014 the IMF recommended that a special clause - called "covenant information" - be included in future debt contracts, through which the debtor commits itself to provide such information (IMF, 2014a:26 and 31). Although the Fund's report did not offer its own standardized clause models, it problematized the content of those from the private association ICMA and considered them appropriately designed (IMF, 2014a:26 and 31).

Taking into account the particularities of the new CAC models, the 2014 report pointed out that all documents related to these clauses should be fully transparent and accessible to the public. In particular, it argued that, before the restructuring offer, creditors should be correctly informed of the qualities of the different CAC voting procedures (IMF, 2014a:26 and 31).

Finally, the Fund encourages debtor states to relate to creditors in a "collaborative manner" (IMF, 2013:10). In pre-default cases, the IMF considers that the speed of an SDR could be essential to avoid a possible default and, therefore, does not require any particular form of discussion (IMF, 2013:11). In other words, in these cases - referred to as "preemptive" cases - the IMF framework does not go forward with a specific modality of debtor-creditors "engagement": it goes a step further by recognizing that in these circumstances a "non-negotiated" restructuring offer may be the most efficient way to proceed (IMF, 2013:11).

2) Specific rules of the IMF's participation in SDR arrears cases. The IMF programs designed to operate in SDR contexts do not usually differ formally from ordinary programs, except when the debtor state is in default. That is why the LIA policy tends to be directly associated with these events (Díaz-Cassou, 2008:9).

Since the mid-1990s, the main Fund's stockholders requested a greater involvement of the private sector in crises. ${ }^{32}$ However, it was not until the early 2000s that the IMF took concrete actions on the matter. In the beginning and similarly to what happened in the 1980s, this involvement sought to be operationalized with contributions from the private sector to financial rescue packages. ${ }^{33}$ Notwithstanding, in 2002 this orientation changed due to the

32 In the SDR field, the private sector involvement was promptly requested by the 1995 Rey Report (Bolton, 2003:42).

33 See, for example, the considerations about the financial package granted to Argentina in December 2000 (IMF, 2004:76). 
modification of the exceptional access policy. Since then, this involvement has been materialized precisely through SDRs. That is to say, the Fund expects private agents to contribute to the recovery of the debtor state by refinancing or reducing their credits (Bolton, 2003:42).

This change in orientation placed the problem of creditors' coordination at the core. In 2002, the Fund advanced in its possible solution through the LIA policy. While originally this policy was designed as an instrument to reduce the power of creditors in SDRs, that year, on the contrary, it was redefined to strengthen it by means of organizing their action collectively and compelling the debtor to negotiate with them during these processes (Simpson 2006:9-10). In fact, the new LIA orientation created a true juridical framework that shows how sovereign states must negotiate with creditors in SDRs (Simpson 2006:9).

Additionally, the new orientation gave legal coverage to the arbitrator role that the IMF was actually exercising in these events (Gelpern, 2016:54). In contexts of default, the Fund's influence on SDRs acquires maximum extension. Materially, this empowerment is the result of the delicate economic situation that the debtor is going through. When the debtor is in default, its need for liquid financial resources increases and the chances of obtaining them outside the IMF decrease (Badd-Buira, 2004:14).

The reverse of the situation is the major financial risk that the Fund assumes in these circumstances. Hence, the relaxation of the no-tolerance policy has been reached only after establishing a series of rigorous conditions that the debtor state in default must meet to have access to Fund financing (IMF, 1989). In these cases, the IMF makes its disbursements only after having made a special review - known as a "financing assurance review" - of the program progress to have sufficient guarantee for the protection of its resources. ${ }^{34}$

The IMF operationalized this new "debtor-creditors engagement" framework at the time of setting the guidelines to interpret the "good faith" criterion incorporated into the LIA policy in 1999 (IMF, 2002b:1). Henceforth, the Fund has considered that the debtor state is making good-faith efforts to reach a collaborative agreement with its creditors if: 1) it rapidly engages in discussions with them and maintains them until an SDR is complete; 2) it timely shares with them relevant information; 3) it provides them an early opportunity for expressing their opinion about the design of the restructuring strategies and instruments (IMF, 2002b:2).

With respect to the first requirement, the IMF explains that the modalities of discussion must be adapted to the individual characteristics of each case. Thus, for example, in simple cases, it is acceptable that the modality is neither formal nor structured. However, in cases where creditors have opportunely created a representative committee, the Fund expects the 
debtor to engage in it in more formal and structured discussions. As a counterpart, it is desirable that in this kind of negotiation creditors agree to suspend their litigations during the SDR process (IMF, 2002b:3).

With respect to the second requirement, the IMF considers that the information that the debtor must share with creditors includes: 1) an explanation of the economic and financial circumstances that justify the activation of the SDR; 2) a synthesis of the economic policies through which it intends to overcome these circumstances; 3) a complete picture of the way in which it plans to treat the different types of creditors - including the official ones - and how such treatment is expected to restore the sustainability of the debt (IMF, 2002b:2). Additionally, if there is a representative committee, there is the expectation that the debtor share with it "confidential" information which allows its creditors to make informed decisions during the SDR event (IMF, 2002b:3).

In relation to the third requirement, the IMF recognizes that there may be circumstances in which the creditors' opinions would also be directed to different dimensions of the program being concomitantly negotiated with the debtor. While such opinions are welcome, the Fund holds it inappropriate to give them a significance which could allow creditors to exercise a sort of veto power over the design of said program (IMF, 2002b:3).

In 2015, the IMF approved a new LIA modality for official creditors that basically entails the same requirements for judging the debtor's good faith (IMF, 2015b:2). As a generic interpretative criterion, the Fund understands that the debtor efforts are in good faith if the absence of an agreement to clear the arrears is not likely to be imputed to it but, on the contrary, to its creditor's unwillingness to negotiate (IMF, 2015b:2). In this sense, the IMF states that this new LIA modality does not seek to alter the preference treatment that the no-tolerance policy concedes to official creditors, but rather to promote their collective action in SDRs (IMF, 2015b:1).

Finally, it is essential to note that the IMF disbursements depend on the effective compliance by the debtor with the LIA framework. The Fund supervises that this actually occurs when the program is approved ${ }^{35}$ or in its subsequent reviews (IMF, 2002b:3). Thus, in SDRs the IMF uses its position as lender of last resort to ensure the effectiveness of the LIA policy in practice.

\section{FINAL REMARKS}

This article aimed to offer an introductory manual to the IMF framework for SDRs. Along with the development of the SDRs, which allow the negotiation of debts with skyrocketing

35 For an example of this kind of control, see the approved program for Argentina (IMF, 2018a). 
figures, the full enforcement of human rights is promoted (A/HRC/20/23, 2011). However, there are no academic works which analyze said framework in depth, which should still be of more concern, considering the need of the international community to understand the content and directionality of the financial reforms carried out in response to the 2008 global crisis.

This article also aimed to fill this gap, and to provide a perspective directed to overcome the partial advances existing in the area. Such perspective takes into account the following methodological precautions: firstly, unlike the antecedents focused on "components", it introduces the framework holistically, showing the way these components are articulated around and along the history of the Fund; secondly, contrary to those articles centered on "functions", this perspective takes "timing" into consideration and shows the role that the IMF plays in SDRs not only by means of financing but also with its surveillance function; finally, unlike other works which emphasize the roles of "agents", the present article lays a bridge between its substantial and procedural rules in order to make the framework visible as an abstract normative structure as well as an action procedure applicable to specific cases.

This particular way of approaching the object of study helps to divide the historical evolution of the framework into four stages.

The first stage develops when all the elements that in the 1980s were part of the current SDR regime emerged or consolidated. Symbolically, this stage began with the fall of the Bretton Woods agreement and came to an end in the late 1970s with the displacement of the Keynesian policies. During this period, the IMF policies of no-tolerance, hard surveillance and conditionality were institutionalized, extending the duration of stand-by credits. Also, the Fund started to intervene in the first crisis of the globalization era, by mediating between debtor states and creditors. This intervention can be found in the documentation of the programs, in which a greater significance of the SDR issues appeared.

The second stage, over the 1980 s, occurred when the current SDR regime consolidated in response to the external debt crisis. In this context, the Fund implemented the so-called "case by case" strategy. The IMF institutionalized the structural conditionalities, the framework to lend access and the LIA policy. The concerted credits and the Brady Plan were a specificity of this stage. The content of the Fund programs expanded and gave birth to the so-called Washington Consensus. The shift in the role played by the IMF and the orientation followed in the 1970s then consolidated by virtue of a larger centrality in global governance and the capacity to mobilize resources.

The third stage took place when the IMF SDR framework acquired the characteristics exhibited today. Symbolically, the Prague conference of 2000 laid out a reform program that called for greater involvement of the private sector. ${ }^{36}$ In this scenario, the exceptional access the IMF” (Press Release, Washington: IMF, September 24, 2000), points 21 and 22. 
framework limited the financial bailout policy, expanding the universe of possible SDR cases. This extension required a major coordination of creditors that the Fund tried to achieve through different CAC models and a new LIA policy orientation. Similarly, analytical instruments aimed at measuring market access and debt sustainability were designed in these years with more precision and consistency (MA and DSA). The IMF surveillance function was decidedly focused on crisis prevention and, in particular, on avoiding over-indebtedness situations. This new institutional scaffolding was completed with the emergence of new guidelines aimed at strengthening the financial management capacity of governments.

There is a final stage when the bulk of this scaffolding was updated. The diagnosis of the framework development over the 2000s was materialized in the 2013 report that promoted a new round of reforms. In fact, these reforms had already begun after the global crisis, with changes in the conditionality guidelines directed to reduce the IMF interference in debtor states internal policy. At the center of this new round, the new models of CACs emerged. These reforms were complemented, on the one hand, with a readjustment of the Fund's lending policy for those states requesting exceptional access credits or being in arrears with official creditors and, on the other, with a modernization of the guidelines to assess debt sustainability and properly manage it.

Finally, it should be mentioned that the described SDR framework was the result of a design process not fully planned but, on the contrary, mostly organized around the need to answer specific circumstances or problems. The latest reforms were inscribed in the SDR regime that emerged in the 1980s in the form that it assumed in the early 2000s.

The depth of these modifications is discussed in the literature, in the context of the more general debate about whether we are or not before an especially renewed IMF after the global crisis. The opinions in this debate cannot be introduced in abstract, since they make sense when considering the standpoint their issuers speak from (Manzo, 2019a:47).

Following the idea that supports the continuity of the current regime, the depth of the performed changes is stressed; it must be noted that the reforms were applied in almost all the relevant areas of the SDR framework (Collyns, 2014:2). At the other extreme, a position that advocates for drafting an international bankruptcy law or similar emerges. From this perspective, the post-global crisis SDR modifications underpin the status quo and, consequently, leave its structural tensions / contradictions intact and do not solve the underlying problems (Manzo, 2019a:79).

The performed analysis sums up the content and operating logic of the current IMF SDR framework as follows.

In relation to the surveillance function, the Fund seeks to prevent financial crises by ordering its instruments and procedures following the two objectives shown below:

1 - Avoiding over-indebtedness situations that could lead to possible SDR cases. To reach this purpose, the IMF makes available a set of guidelines aimed at strengthening the government practices 
to manage international reserves and sovereign debts. These guidelines set a group of basic principles and rules so that governments can reach their objectives, obtaining resources from the sovereign debt market without assuming an excessive financial risk.

Similarly, the IMF sends key messages to the international community about the economic-financial situation of member states. These messages - which, in certain circumstances, assume the form of warnings and recommendations - are reflected in the annual reports. These reports are based on the data collected through article IV consultations. The IMF processes the data using MAA and DSA.

The former instrument provides relevant information about the ability of the scrutinized state to collect funds in the market and the possible factors that could affect this ability. The latter gives information about the weight of the debt in the economy, tracing the debt course, showing its current structure and making different types of projections. The Fund understands that this information is useful to ensure that the conditions that make a SDR necessary can be reversed before they actually take place.

2 - Designing contracts with appropriate rules to organize a potential SDR event. In the absence of an international bankruptcy law or similar, the parties involved in a specific credit operation set their rights and obligations by means of "contracts". The IMF promotes the inclusion of clauses that regulate the way in which said parties should proceed in case of an SDR.

CACs are clauses specifically designed for this purpose. Basically, these clauses allow the debtor state to modify the original terms of its debt if the SDR offer is supported by a predetermined percentage of creditors. The Fund goes one step further by offering standardized models of CACs with different procedures to aggregate the collective will of creditors ("series by series", "two-limbs" or "single-limb”).

The IMF encourages the use, in debt contracts, of pari passu clauses with a particular wording. Its proposed models of pari passu are aimed at preventing judges from using these clauses as sui generis enforcement mechanisms.

Finally, the Fund suggests the inclusion of other types of complementary clauses. Among such clauses can be stressed those aimed at regulating the mode and type of information that debtor states should provide to creditors in a potential SDR process.

With respect to its lending function, the IMF intends to manage or resolve financial crises by organizing SDRs around the components shown below.

1 -Activation of an SDR as a condition for access to its resources. The Fund finances its member states to help them overcome balance of payment problems. In ordinary cases, the IMF expects that said financing, together with an economic policy adjustment, is enough to bring about a catalytic effect on the market agents and to allow the state to serve its debt in the original terms.

However, there are circumstances where this expectation is not a priori viable. These circumstances are reached when the requesting state does not hold a sustainable debt or some 
perspective of market re-access in the short term. In such circumstances, the Fund conditions access to its resources to the start of a prompt SDR process. The IMF also applies conditions when the sovereign debt is sustainable but not "with high probability", although in this case, unlike in previous ones, it does not require that the SDR should be considered from the start as "definitive".

When the debtor state is in default, access to the Fund's resources is granted if and only if said state makes good-faith efforts to reach an agreement with its creditors; such agreement may involve a reduction or refinancing of the sovereign debt.

2 - Designing an SDR plan in light of the IMF lending programs. The content of these programs arises from a discussion between the requesting state and the Fund, but following the rules that the Fund defines to regulate its lending policy. In case of arrears, the IMF expects that creditors also participate in this discussion.

Considering that the decision to activate an SDR has already been made, the Fund's programs are relevant in the design of the SDR plan. Firstly, because these programs define the set of economic policies to overcome the distress situation that affects the debtor economy. Secondly, because the IMF bears influence on the decision about when it is appropriate to activate an SDR during the design of the programs. DSA is the central component in this regard. This is so because if DSA makes visible that the state's debt is not clearly sustainable, the Fund conditions access to its resources precisely to a prompt activation of this kind of events.

Likewise, the IMF collaborates in the selection of the debt to be included and of the strategy and instruments to be used in the SDR process. This collaboration takes place with the Fund's participation in the design of the program. The IMF technical evaluation of the state's economic situation plays a key role, as does the fact that granting IMF resources is subject to the development of an SDR that returns the debt to a sustainability path. Similarly, in default cases, the Fund also exercises its influence by requiring the debtor to enable creditors to give their opinions about the SDR strategy and instruments.

Finally, the IMF helps to decide how much debt is appropriate to restructure by means of its conditionalities. These conditionalities determine the fiscal savings capacity of the state and, consequently, how many of its own resources it could use to pay the debt during a certain period. The gap between, on the one hand, said resources plus the agreed and expected financing and, on the other, the amount of debt to be paid in such period defines the depth of the SDR that should ideally have to be endorsed by the IMF.

3 - Controlling and coordinating the SDR process by virtue of its lending policy. During these events and throughout the program reviews, the Fund supervises the debtor to verify the effective compliance with the agreed policies under penalty of discontinuing its support.

In addition, the IMF usually agrees that the resources that other official or multilateral agents contribute to finance the debtor were synchronized to the times and needs of its 
own program. This means that during the SDR process the Fund generally coordinates in practice the whole universe of DIP investors by means of its no-tolerance and exceptional access frameworks. ${ }^{37}$

Also, the IMF influences the manner in which the parties should engage with each other in their negotiations.

First, the Fund exercises this influence in relation to the flow of information that the state should provide to its creditors. In default cases, the LIA policy defines, with relative precision, the type and form of information to be transmitted, and ties the progress of the program to its effective compliance. In pre-default cases, there are no similar requirements, although the Fund expects them to be defined in the debt contracts: that is to say, the IMF expects the parties to include in the contracts models of CACs and covenant information that accurately regulate the type and form of information to be provided.

Secondly, the Fund organizes the way in which the parties should interact in SDR processes. In this case, there are also differences considering whether the state is or not in default. Indeed, in default cases, the LIA policy ties the continuity of the program to the requirement of a particular form of engagement between the state and its creditors. On the contrary, in pre-default cases, the Fund softens the prescriptions and simply urges the state to interact with its creditors in a "collaborative manner". In both scenarios, the Fund expects the creditor's consent to the SDR offer to be collectively organized using its new proposed CAC models.

In sum, the IMF orders SDR processes in a framework that aims to regulate the practices of all the agents involved in them, during each of the stages and considering their different dimensions.

The technique that the Fund uses to design the SDR framework (in a "residual" manner by means of the interrelation of political and legal frameworks basically created for other purposes) has been legitimized because of its "flexibility" (Boughton et al., 2014:7-8). In fact, for its promoters this technique is not perfect, but it is adequate to organize SDR events since it gives the Fund the ability to adapt the framework to the changing circumstances of the sovereign debt market; an adaptation which can be achieved without incurring in jumps and discontinuities which could increase uncertainty and, consequently, the financing costs (Gelpern, 2016:56-57).

However, this technique has also been criticized from different perspectives. From an orthodox perspective external to the IMF, it has been argued that the framework is not really

37 In the 1980s, this coordination was institutionalized by means of the concerted credits. Currently, there is not a set of rules that integrally regulate it, although the 2016 reform of the exceptional access framework defined specific prescriptions in this regard (IMF, 2016a:4-5). 
“pro-market” (Manzo, 2019a:67-73). This is so because, under its domain, the SDR events are not spontaneously regulated by contracts, but by a set of rules external to the involved parties. Some of these rules are mandatory, while others that are apparently voluntary in fact are not, because the official sector is the one that designs and communicates said rules. This sector intervenes even in the way in which contracts must be written (Scott, 2006:35). Therefore, the framework interferes in the self-reproductive logic of the market, giving way to practices and institutions that generate the conditions that make SDRs necessary to be maintained over time.

From the perspective of those who advocate for an international bankruptcy law or similar, the IMF technique has been questioned in terms of "legitimacy" and "efficiency". With respect to "legitimacy", the Fund is in itself a creditor and its governance is largely controlled by the G7 countries. Therefore, the IMF should not be an arbitrator, as it is an interested party in SDR processes (Krueger, 2002:23). Also, it should be noted that the framework rules have been created in many cases without following the principles and procedures that ensure that the mandates of a political authority may be held as truly democratic (Rieger, 2016).

Concerning "efficiency", it is argued that SDRs are conflictive processes in which the agents compete with structurally unequal powers. That is why, in the domestic sphere, all the states have decided to regulate corporate restructurings through a specific law and with the intervention of a special court (Bolton, 2003). In the international sphere, the IMF organizes SDRs following a framework that is designed with juridical modalities of different origin, hierarchy and degree of scope and validity. Also, it leaves unregulated aspects which domestic legislations define as crucial to the proper development of these processes. Consequently, the framework is seen as incomplete, relatively imprecise and of difficult accessibility and intelligibility. Accordingly, it is stated that when SDRs become complex, the disputes tend to be resolved leaving the IMF rules aside and following the primacy of the law of the fittest (Manzo, 2019a:73-89).

\section{REFERENCES}

A/HRC/20/23. "Report of the Independent Expert on the effects of foreign debt (...) on the full enjoyment of all Human Rights (...)”(UN General Assembly, April 10, 2011).

Babb, Sarah and Ariel Buira. "Mission Creep, Mission Push and Discretion in Sociological Perspective:The Case of IMF Conditionality” (Geneva: XVIII G24Technical Group Meeting, March 8-9, p. 1-34, 2004). 
Bolton, Patrick. "Toward a Statutory Approach to SDR: Lessons from Corporate Bankruptcy Practice Around the World" (IMFWorking Paper, special issue, Vol. 50, p. 57, 2003).

Boughton, James. “The IMF: What Is It Good for?” (Washington: PIIE, Conference, p. 4-7, April 8, 2014).

Boughton, James. Silent Revolution:The International Monetary Fund 1979-1989 (Washington, IMF, 2001).

Boughton, James. Skylar Brooks and D. Lombardi [Boughton et al.], "IMF Lending Practices and Sovereign Debt Restructuring" (CIGI Papers 41, June 1-15, 2014).

Bourdieu, Pierre. "La fuerza del derecho", Elementos para una sociología del campo jurídico (Bogotá: Siglo del Hombre Editores, p. 155-220, 2000).

Buchheit, Lee; Guillaume Chabert; DeLong, Chanda; Jeromin Zettelmeyer [Buchheit et al.]. "The Sovereign Debt Restructuring Process" (Washington: IMF, draft chapter 8, September 4, 2018).

Buira, Ariel. "An Analysis of IMF Conditionality" (Discussion Paper Series, G24: UN, No. 22, p. 1-30, August 2003).

Collyns, Charles. “The IMF: What Is It Good for?” (Washington: PIIE, Conference, April 8, 2014).

De Angelis, Massimo. "Neoliberal governance, reproduction and accumulation" (The Commoner, 7, SpringSummer, p. 1-28, 2003).

Díaz-Cassou, Javier, Aitor Erce-Domínguez and Juan Vázquez-Zamora [Díaz-Cassou et al.]. "The Role of the IMF in Recent SDRs: Implications for the Policy of LIA” (Documentos Ocasionales, Banco de España: Madrid, No. 0805, p. 1-37, 2008).

Gelpern, Anna. “Sovereign Debt: Now What?” (TheYale Journal of International Law 41-2, p. 45-96, 2016).

Gelpern, Anna. “The IMF: What Is It Good for?” (Washington: PIIE, Conference, April 8, 2014, p. 23-26).

Gulati, M. and Gelpern, A. "Public Symbol in Private Contract: A Case Study" (Washington University Law Quarterly 84-7: 1-91, 2006).

Guscina, Anastasia, Malik Sheheryar and Michael Papaioannou [Guscina et al.]. "Assessing Loss of Market Access: Conceptual and Operational Issues” (IMFWorking Paper, Washington: IMF, WP/17/246, p. 2-63, November 2017). 
Guzmán, Martín and Joseph E. Stiglitz. "Fixing Sovereign Debt Restructuring” (New York: UNCTAD, Ad Hoc UN Committee for SDRM, 2014).

Haley, James. “Sovereign Debt Restructuring: Bargaining for Resolution” (CIGI Papers 124, April 2017).

Haley, James. “Sovereign Debt Restructuring: Old Debates, New Challenges” (CIGI Papers 32, May 2014).

Horsefield, J. Keith. "The IMF 1945-1965. Twenty Years of International Monetary Cooperation” (Washington: IMF, Volume I: Chronicle, 1969).

IMF. "Communiqué of the International Monetary and Financial Committee of the Board of Governors of the IMF" (Press Release, Washington: IMF, September 24, 2000).

Krueger, Anne. A New Approach to Sovereign Debt Restructuring (Washington: IMF, 2002).

Krueger, A. and S. Hagan. "Sovereign Workouts: An IMF Perspective" (Chicago Journal of International Law 6-1:203-18, 2005).

Kupelian, R. and M. Sol Rivas. "Vulture Funds: The Lawsuit Against Argentina and the Challenge They Pose to the World Economy” (Buenos Aires: CEFIDAR Working Paper 49, 2014).

Lee, Pei-shan. "Neoliberal Diffusion and Regulatory Capture of Financial Rules: Lessons from the 20078 Global Financial Crisis" (Public Administration \& Policy 55, p. 109-136, December 2012).

Lombardi, Domenico. “The IMF: What Is It Good for?” (Washington: PIIE, Conference, April 8, 2014).

Makoff, Gregory and Robert Kahn. "Sovereign Bond Contract Reform Implementing the New ICMA" (CIGI Papers 56, February 1-21, 2015).

Manzo, Alejandro. "Where do they speak from? Positions about the new IMF contractual proposal for ordering sovereign debt restructurings" (Revista Direito e Práxis, 10-1, 41-100, 2019a).

Manzo, Alejandro. “¿Gobernanza financiera?: comparación de las matrices políticas de las que emergieron las CACs 2003 y 2014” (Revista Direito GV, 15-1, 1-31, 2019).

Manzo, Alejandro. "Reestructuraciones de deuda soberana: el debate sobre su regulación en términos de disputa por la gobernanza global” (Revista Direito e Práxis, 9-1, p. 9-45, 2018).

Maziar, Minovi. “The IMF:What Is It Good for?” (Washington: PIIE, Conference, p. 7-10, April 8, 2014). 
Navarrete, Jorge. "Política exterior y negociación financiera internacional: la deuda externa y el Consenso de Cartagena” (Revista de la CEPAL 27, p. 7-27, December 1985).

PIIE. “The IMF: What Is It Good for?” (Washington: PIIE, Conference, April 8, 2014).

Riegner, Michel. "Legal Frameworks and General Principles for Indicators in Sovereign Debt Restructuring” (TheYale Journal of International Law 41-2, p. 141-176, 2016),

Schadler, Susan. “The IMF: What Is It Good for?” (Washington: PIIE, Conference, p. 26-29, April 8, 2014).

Schadler, Susan. "Ukraine and the IMF's Evolving Debt Crisis Narrative" (CIGI Policy Brief 68, November 2015).

Schadler, Susan. "Does the Level of Public Debt Matter?" (CIGI Policy Brief 76, April, 2016).

Scott, Hal. "Sovereign Debt Default: Cry for the United States, not Argentina" (Washington Legal Foundation, Critical Legal Issues: working paper series No. 140, September 2006).

Simpson, Lucio. "The role of the IMF in debt restructurings: lending into arrears, moral hazard and sustainability concerns” (UN, G24 Discussion Paper No. 40, May 2006).

Skylar, Brooks and Domenico Lombardi. "Sovereign Debt Restructuring” (CIGI Papers 64, April 1-20, 2015).

Sobel, Mark. "Strengthening Collective Action Clauses: Catalyzing Change - The Back Story" (Capital Markets Law Journal 11-1:3-11, 2016).

Tran, Hung. "The IMF: What Is It Good for?” (Washington: PIIE, Conference, p. 28-30, April 8, 2014).

Weidemaier, Mark and Mitu Gulati. “A People's History of Collective Action Clauses” (Virginia Journal of International Law, 54: 51-95, 2013). 
IMF SOVEREIGN DEBT RESTRUCTURING FRAMEWORK: ORIGIN, EVOLUTION AND LATEST UPDATES OF ITS MAIN COMPONENTS : $4 \mathbf{1}$

ANNEX. IMF SDR Framework: OfFicial Documents

\section{IMF Crisis Prevention}

\section{1 - IMF ASSESSMENT OF THE SDR FRAMEWORK}

“SOVEREIGN DEBT RESTRUCTURING: RECENT DEVELOPMENTS AND IMPLICATIONS FOR THE FUND'S LEGAL AND POLICY FRAMEWORK" (IMF REPORT, WASHINGTON: IMF, APRIL, 2013)

“PROGRESS REPORT ON INCLUSION OF ENHANCED CONTRACTUAL PROVISIONS IN INTERNATIONAL SOVEREIGN BOND CONTRACTS" (IMF REPORT, WASHINGTON: IMF, 2015)

“SECOND PROGRESS REPORT ON INCLUSION OF ENHANCED CONTRACTUAL PROVISIONS IN INTERNATIONAL SOVEREIGN BOND CONTRACTS" (IMF REPORT, WASHINGTON: IMF, 2017)

\section{2 - PUBLIC DEBT MANAGEMENT}

“GUIDELINES FOR PUBLIC DEBT MANAGEMENT" (IMF POLICY PAPER, WASHINGTON: IMF, MARCH 21, 2001, P. 1-37)

“GUIDELINES FOR PUBLIC DEBT MANAGEMENT: AMENDED” (IMF POLICY PAPER, WASHINGTON: IMF, DECEMBER 9, 2003, P. 1-38)

“GUIDELINES FOR PUBLIC DEBT MANAGEMENT: ACCOMPANYING DOCUMENT AND SELECTED CASE STUDIES” (IMF GUIDELINES, WASHINGTON: IMF, 2003A, P. 1-272)

“REVISED GUIDELINES FOR PUBLIC DEBT MANAGEMENT” (IMF POLICY PAPER, WASHINGTON: IMF, APRIL 1, 2014, P. 1-42)

\section{3 - FOREIGN EXCHANGE RESERVE MANAGEMENT}

"GUIDELINES FOR FOREIGN EXCHANGE RESERVE MANAGEMENT" (IMF POLICY PAPER, WASHINGTON: IMF, SEPTEMBER 20, 2001A, P. 1-321

“GUIDELINES FOR FOREIGN EXCHANGE RESERVE MANAGEMENT: ACCOMPANYING DOCUMENT” (IMF POLICY PAPER, WASHINGTON: IMF, MARCH 26, 2003B, P. 1-39]

“REVISED GUIDELINES FOR FOREIGN EXCHANGE RESERVE MANAGEMENT” (IMF POLICY PAPER, WASHINGTON: IMF, FEBRUARY 1, 2013A, P. 1-43)

4 - CONTRACTUAL CLAUSES: CACS AND PARI PASSU CLAUSES

“COLLECTIVE ACTION CLAUSES: RECENT DEVELOPMENTS AND ISSUES” (IMF POLICY PAPER, WASHINGTON: IMF, MARCH 25, 2003C, P. 1-28) 
IMF SOVEREIGN DEBT RESTRUCTURING FRAMEWORK: ORIGIN, EVOLUTION AND LATEST UPDATES OF ITS MAIN COMPONENTS : $4 \mathbf{2}$

“THE RESTRUCTURING OF SOVEREIGN DEBT - ASSESSING THE BENEFITS, RISKS, AND FEASIBILITY OF AGGREGATING CLAIMS" (IMF POLICY PAPER, WASHINGTON: IMF, SEPTEMBER 3, 2003D, P. 1-33)

“STRENGTHENING THE CONTRACTUAL FRAMEWORK TO ADDRESS COLLECTIVE ACTION PROBLEMS IN SOVEREIGN DEBT RESTRUCTURING" (IMF POLICY PAPER, WASHINGTON: IMF, SEPTEMBER 2, 2014A, P. 1-48)

\section{5 - DEBT SUSTAINABILITY ANALYSIS (DSA)}

“ASSESSING SUSTAINABILITY” (IMF POLICY PAPER, WASHINGTON: IMF, MAY 28, 2002, P. 1-60)

“SUSTAINABILITY ASSESSMENTS - REVIEW OF APPLICATION AND METHODOLOGICAL REFINEMENTS” (IMF POLICY PAPER, WASHINGTON: IMF, JUNE 10, 2003E, P. 1-72)

“INFORMATION NOTE ON MODIFICATIONS TO THE FUND'S DEBT SUSTAINABILITY ASSESSMENT FRAMEWORK FOR MARKET ACCESS COUNTRIES" (IMF INFORMATION NOTE, WASHINGTON: IMF, JULY 1, 2005, P. 1-11) “MODERNIZING THE FRAMEWORK FOR FISCAL POLICY AND PUBLIC DEBT SUSTAINABILITY ANALYSIS" (IMF POLICY PAPER, WASHINGTON: IMF, AUGUST 5, 2011, P. 1-58)

“STAFF GUIDANCE NOTE FOR PUBLIC DEBT SUSTAINABILITY ANALYSIS IN MARKET-ACCESS COUNTRIES” (STAFF GUIDANCE NOTE, WASHINGTON: IMF, MAY 9, 2013B, P. 1-54]

“JOINT WORLD BANK-IMF DEBT SUSTAINABILITY FRAMEWORK FOR LOW-INCOME COUNTRIES" (FACTSHEET, WASHINGTON: IMF, MARCH 19, 2019)

“DEBT SUSTAINABILITY ANALYSIS FOR MARKET-ACCESS COUNTRIES” (FACTSHEET, WASHINGTON: IMF, AUGUST 15, 2018)

\section{6 - MARKET ACCESS ANALYSIS (MAA)}

“ASSESSING THE DETERMINANTS AND PROSPECTS FOR THE PACE OF MARKET ACCESS BY COUNTRIES EMERGING FROM CRISES" (IMF POLICY PAPER, WASHINGTON: IMF, SEPTEMBER 6, 2001C, P. 1-40)

“ASSESSING THE DETERMINANTS AND PROSPECTS FOR THE PACE OF MARKET ACCESS BY COUNTRIES EMERGING FROM CRISES - COUNTRY CASES" (IMF POLICY PAPER, WASHINGTON: IMF, SEPTEMBER 13, 2001B, P. 1-77) “ASSESSING THE DETERMINANTS AND PROSPECTS FOR THE PACE OF MARKET ACCESS BY COUNTRIES EMERGING FROM CRISES: FURTHER CONSIDERATIONS" (IMF POLICY PAPER, WASHINGTON: IMF, MARCH 1, 2005A, P. 1-32) “FURTHER CONSIDERATION OF A NEW LIQUIDITY INSTRUMENT FOR MARKET ACCESS COUNTRIES - DESIGN ISSUES" (IMF POLICY PAPER, WASHINGTON: IMF, FEBRUARY 13, 2007, P. 1-25)

7 - ARTICLE IV CONSULTATIONS: THE ARGENTINEAN CASE AS AN EXAMPLE

“SUPERVIZACIÓN ECONÓMICA”, IN “INFORME ANUAL DEL FMI 2017: PROMOVER EL CRECIMIENTO INCLUSIVO" (CAPÍTULO DE INFORME,WASHINGTON: IMF, 2017A, P. 32-45) 
IMF SOVEREIGN DEBT RESTRUCTURING FRAMEWORK: ORIGIN, EVOLUTION AND LATEST UPDATES OF ITS MAIN COMPONENTS : $4 \mathbf{3}$

“SUPERVIZACIÓN DEL FMI” (FACTSHEET,WASHINGTON: IMF, MARZO, 2016, P. 1-3)

“ARGENTINA 2016 ARTICLE IV CONSULTATION - PRESS RELEASE, STAFF REPORT AND STATEMENT BY THE EXECUTIVE DIRECTOR FOR ARGENTINA" (IMF COUNTRY REPORT NO. 16/346, WASHINGTON: IMF, NOVEMBER, 2016, P. 1-93)

“ARGENTINA 2017 ARTICLE IV CONSULTATION - PRESS RELEASE, STAFF REPORT AND STATEMENT BY THE EXECUTIVE DIRECTOR FOR ARGENTINA" (IMF COUNTRY REPORT NO. 17/409, WASHINGTON: IMF, DECEMBER, 2017B, P. 1-83)

\section{imf Crisis Management and Resolution}

\section{1 - EXCEPTIONAL ACCESS}

“ACCESS POLICY IN CAPITAL ACCOUNT CRISES" (IMF POLICY PAPER, WASHINGTON: IMF, JULY 29, 2002A, P. 1-51)

“THE FUND'S LENDING FRAMEWORK AND SOVEREIGN DEBT - PRELIMINARY CONSIDERATIONS” (IMF POLICY PAPER, WASHINGTON: IMF, JUNE, 2014B, P. 1-42I

“THE FUND'S LENDING FRAMEWORK AND SOVEREIGN DEBT - FURTHER CONSIDERATIONS” (IMF POLICY PAPER, WASHINGTON: IMF, APRIL, 2015A, P. 1-99)

“REVIEW OF ACCESS POLICY UNDER THE CREDIT TRANCHES AND THE EXTENDED FUND FACILITY” (IMF POLICY PAPER, WASHINGTON: IMF, JANURY 14, 2003F, P. 1-19]

“IMF EXECUTIVE BOARD APPROVES EXCEPTIONAL ACCESS LENDING FRAMEWORK REFORMS” (PRESS RELEASE, WASHINGTON: IMF, JANUARY 29, 2016A, NO. 16/31)

“INFORME SOBRE LA EVALUACIÓN DEL PAPEL DEL FMI EN ARGENTINA, 1991-2001” IOFICINA DE EVALUACIÓN INDEPENDIENTE, WASHINGTON: IMF, JULY 30, 2004, P. 1-184)

\section{2 - LENDING INTO ARREARS (LIA)}

“IMF POLICY ON LENDING INTO ARREARS TO PRIVATE CREDITORS” (IMF POLICY PAPER, WASHINGTON: IMF, 1999, P. 1-16)

“REFORMING THE FUND'S POLICY ON NON-TOLERATION OF ARREARS TO OFFICIAL CREDITORS” IIMF POLICY PAPER, WASHINGTON: IMF, DECEMBER, 2015B, P. 1-34)

“SELECTED DECISIONS AND SELECTED DOCUMENTS OF THE INTERNATIONAL MONETARY FUND (IMF PERIODICALS", WASHINGTON: IMF, MARCH 31, 2017C, P. 1-1035)

“FUND POLICY ON LENDING INTO ARREARS TO PRIVATE CREDITORS - FURTHER CONSIDERATION OF THE GOOD FAITH CRITERION" (EXECUTIVE BOARD MEETING 02/92, SUMMING UP BY THE CHAIRMAN, WASHINGTON: IMF, SEPTEMBER 4, 2002B) 
IMF SOVEREIGN DEBT RESTRUCTURING FRAMEWORK: ORIGIN, EVOLUTION AND LATEST UPDATES OF ITS MAIN COMPONENTS : $4 \mathbf{4}$

“FUND INVOLVEMENT IN THE DEBT STRATEGY" (EXECUTIVE BOARD MEETING 89/61, SUMMING UP BY THE CHAIRMAN, WASHINGTON: IMF, MAY 23, 1989)

3- IMF CONDITIONALITIES: GUIDELINES

IMF, “2011 REVIEW OF CONDITIONALITY - OVERVIEW PAPER” (IMF POLICY PAPER, WASHINGTON: IMF, JUNE 19, 2012, P. 1-29)

IMF, “CONDITIONALITY IN FUND-SUPPORTED PROGRAMS - POLICY ISSUES” (IMF POLICY PAPER, WASHINGTON: IMF, FEBRUARY 16, 2001B, P. 1-83)

IMF, “THE MODALITIES OF CONDITIONALITY - FURTHER CONSIDERATIONS” (IMF POLICY PAPER, WASHINGTON: IMF, JANUARY 8, 2002C, P. 1-48)

IMF, “GUIDELINES ON CONDITIONALITY” (IMF GUIDELINES, WASHINGTON: IMF, SEPTEMBER 25, 2002D, P. 1-11)

IMF, “GUIDELINES ON CONDITIONALITY FOR THE USE OF THE FUND'S RESOURCES AND FOR STAND-BY ARRANGEMENTS" (IMF GUIDELINES, WASHINGTON: IMF, DECISION NO. 6056-79/38, MARCH 2, 1979) IMF, “STATEMENT OF THE IMF STAFF PRINCIPLES UNDERLYING THE GUIDELINES ON CONDITIONALITY REVISED" (IMF STATEMENT, WASHINGTON: IMF, JANUARY 9, 2006, P. 1-11)

IMF, “APPLICATION OF STRUCTURAL CONDITIONALITY - 2009 ANNUAL REPORT” (IMF ANNUAL REPORT, WASHINGTON: IMF, MARCH 9, 2010, P. 1-14)

IMF, “GRA LENDING TOOLKIT AND CONDITIONALITY - REFORM PROPOSALS" (IMF POLICY PAPER, WASHINGTON: IMF, MARCH 13, 2009, P. 1-50)

IMF, “GRA LENDING TOOLKIT AND CONDITIONALITY - REFORM PROPOSALS - SUPPLEMENT 1" (IMF POLICY PAPER, WASHINGTON: IMF, MARCH 19, 2009A, P. 1-29]

IMF, “MODIFICATIONS OF THE FUND'S CONDITIONALITY FRAMEWORK - APPLICATION TO THE POLICY SUPPORT INSTRUMENT" (IMF POLICY PAPER, WASHINGTON: IMF, APRIL 13, 2009B, P. 1-3)

\section{4 - DEBT LIMITS}

“STAFF GUIDANCE NOTE ON THE IMPLEMENTATION OF PUBLIC DEBT LIMITS IN FUND-SUPPORTED PROGRAMS" (IMF GUIDANCE NOTE, WASHINGTON: IMF, MAY 27, 2015C, P. 1-33)

“REFORM OF THE POLICY ON PUBLIC DEBT LIMITS IN FUND-SUPPORTED PROGRAMS” (IMF POLICY PAPER, WASHINGTON: IMF, DECEMBER 4, 2014C, P. 1-45)

“DEBT LIMITS IN FUND-SUPPORTED PROGRAMS: PROPOSED NEW GUIDELINES” (IMF POLICY PAPER, WASHINGTON: IMF, AUGUST 5, 2009C, P. 1-36) 
5 - IMF LENDING PROGRAMS AND REVIEWS: THE ARGENTINEAN CASE AS AN EXAMPLE

“IMF EXECUTIVE BOARD APPROVES US\$50 BILLION STAND-BY ARRANGEMENT FOR ARGENTINA” (PRESS RELEASE NO. 18/245, WASHINGTON: IMF, JUNE 20, 2018A)

“ARGENTINA REQUEST FOR STAND-BY ARRANGEMENT" (IMF STAFF COUNTRY REPORT NO. 18/219, WASHINGTON: IMF, JUNE 13, 2018B)

“ARGENTINA LETTER OF INTENT" (APPENDIX I TO STAFF COUNTRY REPORT N0. 18/219, WASHINGTON: IMF, JUNE 12, 2018C, P. 64-65)

“ARGENTINA MEMORANDUM OF ECONOMIC AND FINANCIAL POLICIES" (ATTACHMENT I TO STAFF COUNTRY REPORT NO. 18/219, WASHINGTON: IMF, JUNE 12, 2018D, P. 66-83)

“ARGENTINA TECHNICAL MEMORANDUM OF UNDERSTANDING” (ATTACHMENT II TO STAFF COUNTRY REPORT NO. 18/219, WASHINGTON: IMF, JUNE 12, 2018E, P. 84-98)

“FIRST REVIEW UNDER THE STAND-BY ARRANGEMENT” (IMF COUNTRY REPORT NO. 18/297, WASHINGTON: IMF, OCTOBER, 2018F)

\section{HOW TO QUOTE THIS ARTICLE:}

MANZO, Alejandro Gabriel. IMF Sovereign Debt Restructuring Framework: Origin, Evolution and Latest Updates of its Main Components. Revista Direito GV, v. 16, n. 2, maio/ago. 2020, e1965. doi: http://dx.doi.org/ 10.1590/2317-6172201965
Alejandro Gabriel Manzo

Adjunct Research Member of Consejo Nacional de InVEStigaciones CientífICAS Y TÉcnicas (CONICET) (National Council of Science and Technology Research), at Centro de Investigaciones Jurídicas y Sociales (CIJS) (Law and Social Research Centre) of Universidad Nacional de Córdoba (UNC), Argentina. Ph.D. in LaW and Social Sciences, UNC. Master in Sociology, UNC. Master in SOCIOLOGY OF LAW, OÑATI INTERNATIONAL INSTITUTE FOR THE SOCIOLOGY OF LAW (IISJ), SPAIN. alemanzzolahotmail.com 